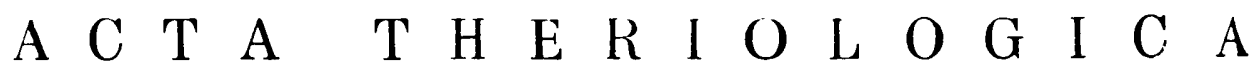

VOL. XII, 13: 191-222.

BIAŁOWIEŻA

30.VII.1967

Alina KOSTELECKA - M Y R C H A

\title{
Variation of Morpho-Physiological Indices of Blood in Clethrionomys glareolus (Schreber, 1780)
}

[With 15 Figs. \& 10 Tables]

Studies on the blood picture of $C$. glareolus make it possible to state that the morphological adaptive mechanism which secures the adequately high level of the function of haemoglobin depends on the environmental and physiological conditions of the organism. This mechanism consists in a change in the haemoglobin content of blood and in the directly proportional subordinate change of haematocrit, thanks to which the $M C H C$ is always nearly the same. The value of haematocrit results from the changes in the number and size of erythrocytes. The correlations between these indices and the direction and intensity of their changes, which determine the total surface area of erythrocytes, seem to be essential in this respect. The number of blood cells is inversely proportional to temperature and their diameter changes in direct relation to the changes in day length. As a result, the function of haemoglobin reaches its highest level in the winter and spring, and $\mathrm{So}$ in the periods of increased oxygen requirements of the organism. The number and size of erythrocytes are dependent on the age of animals examined and on such physiological conditions as pregnancy and lactation. The number of erythrocytes of $C$. glareolus increases up to the 30th day of postnatal development and though their diameter is smaller, it is in the end responsible for a remarkable increase in the total surface area of erythrocytes. This mechanism may be regarded as one of the essential processes providing a juvenile for completely independent ways of living.

A comparison of the blood picture of C. glareolus with those of other laboratory Microtidae and the lack of differences in the morphological indices of blood between the highland and lowland populations of the bank vole suggest that this species has better conditions of gaseous exchange than many other rodents. This fact seems to account, to a great extent, for the faculty of $C$. glareolus for living in various environments and for its wide range.

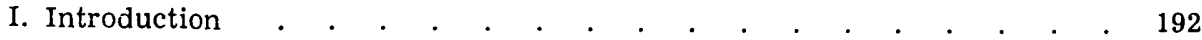

II. Material and method . . . . . . . . . . . . . . . . 194

III. Normal values of morphological indices of blood of C. glareolus as compared with those of other laboratory Microtidae. 
IV. Blood indices during pregnancy and lactation . . . . . . . 198

V. Variation of morphological indices of blood in the postnatal development 196

VI. Seasonal variation . . . . . . . . . . . . . . .

VII. The effect of day length and temperature on the morphological picturc of blood

VIII. Morphological indices of blood of a highland population

IX. Discussion References Streszczenie

\section{INTRODUCTION}

Haemoglobin, which plays so important a role in the process of respiration of an organism, has excited particular attention both of biologists and of physicians. Consequently, in the opulent haematological literature much attention has been paid to the morphological indices of blood which characterize its function. Investigators, above all, attempted to establish the normal values of these indices because of their great importance to medical diagnoses as well as to the characterization of species. The results of these studies, carried out mainly on laboratory animals, have already been collected in monographic works ( $\mathrm{S}$ ch ermer, 1958; B a rański et al., 1962; He in e c k e, 1962).

The values of blood indices determined for a species under laboratory conditions on the basis of material which is uniform both genetically and in respect of age are naturally adequate to only some of the comparative purposes. For this reason, many authors investigated these indices on laboratory animals in the aspect of age and sex variation, taking into account the physiological conditions of animals ( $\mathrm{S} \mathrm{ith}$, 1932; Rosahn et al., 1934; Bruner et al., 1938; Alperovich, 1939; Gr üneber g, 1942; S tewart et al., 1944; Duvolon, 1947; G a r d ner, 1947a, b, c, d; de Rosa, 1947; Bidder \& Undritz, 1948; Kunze, 1954; Pujman et al., 1955; Svihla \& Bowman, 1955; Stevens \& Mackensen, 1958; Schulz \& M uller, 1962; Boegler, 1963).

Relatively much attention has been given to animals of special economic importance. Not only have the normal values of their blood indices been established (F errar a, 1951; K or žuev \& G ol'd far b, 1954; B a rnecki et al., 1960; S a 1ganska, 1962; Mazurkiewicz, 1966), but also the dependence of these indices upon the age of specimens under study ( $\mathrm{Ch}$ e y mol \& H enry, 1947; Nikolska$\mathrm{ja}, 1962$; Holman \& Dew, 1964), their seasonal variation (Akopjan, 1941; Sat a 1 in a, 1946; B ondarenko, 1952; Vasenko et al., 1953; B a lbierz et al., 1962; G or odeckij, 1962) and variation with altitude above sea-level (A $\mathrm{rav}$ \& Martynova, 1952; Zaharia n, 1963) have been studied.

Wild-living rodents, an abounding group of mammals with a wide range of occurrence, are undoubtedly a good object for comparative studies. Knowledge of the blood indices associated with the function of haemoglobin in these animals, which live under very various conditions and show great differences in their biology, is especially important to the studies on the adaptive mechanisms in mammals. Literature has already provided many data obtained for adult rodents inhabiting different regions (L i e b \& Wil ber, 1954; M u s c chi a et al., 1955; F or e man, 1956 and others). Rodents which dwell in uplands claim special attention on 
account of the specificity of the environment, characterized, above all, by a comparatively low partial pressure of oxygen.

Comparative studies of the blood indices of forms which occur only in the highlands and those living both in the highlands and in the lowlands and observations on the changes in the blood picture of rodents from the highlands transferred to the lowlands and vice versa, as well as the experimental data concerning the responses of some species to a decrease in the partial pressure of oxygen, have

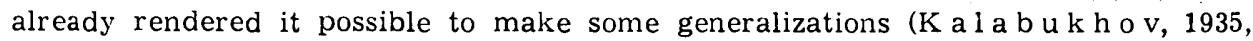
1937; Kalabukhov \& Rodioncv, 1936; Norrison et al., 1963a, b; M orris o n, 1964).

K or žu ev (1964) made use of these data demonstrating the role of haemoglobin in the evolution of animals. Observations on the development of the respiratory function of haemoglobin in ontogenesis, made at the same time and analysed by I r žak (1964), supply indispensable facts for contemporary evolutional analyses.

In extensive comparative studies conducted on wild-living animals, which are directly exposed to all sorts of changes taking place in their environment, it is especially important to get knowledge of seasonal variation of the blood indices cnsuring a suitable intensity of gaseous exchange to the organism. In the haematological literature of this problem there are, however, only few data on rodents (K a l a bukhov, 1953; K ozakevi č, 1959; S e a l and er, 1960; N ew s on, 1962; Newson \& Chitty, 1962; Kunicki-Goldfinger \& Kunicka-Goldf inger, 1964).

Some of the animals of this group have exceptionally wide ranges. The knowledge of adaptive mechanisms with which these animals are provided may be helpful to explain the physiological sources of the evolutionary power of the species. The bank vole Clethrionomys glareolus (S chreber, 1780), which inhabits both the lowlands and the highlands in Scotland and in Siberia, as well as in the Scandinavian, Apennine and Iberian Peninsulas and in Asia Minor, seems to be a good object for such studies. The respiratory function of haemoglobin, sensitive to changes in the environment and to different physiclogical conditions, can undoubtedly be a good indicator in determination of adaptive possibilities of the species.

In connection with the above the objective of the present work was to examine the morphological indices of blood, characterizing the function of haemoglobin in C. glareolus. The variation of these indices was traced in the postnatal development and in the full annual cycle. In order to make a detailed interpretation of seasonal changes possible, the effect of temperature and day length upon the blood picture was studied under laboratory condition. The values of blood indices during pregnancy and lactation were established for females and the data obtained for highland ind lowland populations of $C$. glareolus were compared. The bank vole has all the characters necessary to make it a good laboratory animal. For this reason, the normal range of fluctation of the blood indices which characterize the functicn of haemoglobin was determined for a laboratory 
colony of the bank vole. The normal blood picture, defined on the basis of animals living under unchanging laboratory conditions for many generations, may be assumed as a fiducial point for further comparisons.

\section{MATERIAL AND METHOD}

A total of 707 specimens of C. glareolus were examined, of which 280 were derived from several years' rearing in the Mammals Research Institute, Polish Academy of Sciences, at Białowieża. These animals had been kept in almost the same thermal $\left(18^{\circ} \mathrm{C}-20^{\circ} \mathrm{C}\right)$, humidity $(70 \%-80 \%)$ and light (long day - about $18 \mathrm{hrs}$ ) conditions for some dozen generations.

Their main food, offered in excess, was oats; in addition they were given beets, carrots, acorns and green parts of plants. The bank voles were kept in pairs in cages with measurements of $15 \mathrm{~cm} \times 25 \mathrm{~cm} \times 40 \mathrm{~cm}$, furnished with a waterfountain. The cages were littered with peat and had a separate nest filled with hay.

In order to determine the normal values of morphological indices of $C$. glareolus under laboratory conditions, 32 specimens, 5-6 months old, were examined. The effect of pregnancy and lactation upon these indices was studied on 20 females and the dependence of the blood picture upon the age of bank voles was manifested using 228 animals, 0-70 days old. Out of the 427 free-living specimens, 412 were collected in the Białowieża National Park, in the biotope Querco-carpinetum stachyetosum R. Tx., and 15 in the Tatra Mts; 322 wild-living bank voles from Białowieża were caught at one-month intervals (in the second week of each month) during the whole annual cycle. Ninety specimens were taken in autumn and divided into 3 experimental groups to determine the influence of the day length and temperature on the blood indices. The Tatra specimens were caught at an altitude of $1750 \mathrm{~m}$, in the region of Morskie Oko Lake at the end of September and the beginning of October 1965 to compare their blood indices with the data obtained for the Białowieża population.

In the field, bank voles were caught in live-traps and brought to the laboratory once a day, in the morning. Blood was taken from the cervical vein of animals anaesthesized with ether always between 9 a.m. and 11 a.m. to avoid differences which might have been caused by the daily variation of some indices.

The haemoglobin content in $100 \mathrm{ml}$. of blood $(\mathrm{g} \%)$ was examined using a Zeiss haemometer. The number of erythrocytes in 1 cu.mm of blood was established by counting them in 30 quadrates of Thoma's network. On account of their large numbers the dilution was still weakened by taking less blood by two-fifth and this difference was made up in calculations. The diameter of erythrocytes was measured with a Zeiss eye-piece micrometer on smears of blood stained by the Pappenheim method. The means obtained from several series (50 measurements in each) from the same preparation did not differ significantly. Having made a large number of such tests for different groups of animals under study, I established that it is enough to take measurements of 50 erythrocytes in each specimen to obtain the mean which will well characterize the average diameter of erythrocytes. The percentage number of cells was determined using a microhaematocrit in this manner that blood was centrifuged in heparinized capillaries at $6000 \mathrm{rpm}$ for 3 minutes. In addition, the formulae given by $\mathrm{W}$ in $\mathrm{trobe}$ (1956) were used to calculate the mean corpuscular haemoglobin $(M C H)$, the average volume of red cells, the mean corpuscular haemoglobin concentration $(M C H C)$ and, after finding 
that the distribution of measurements of erythrocyte diameters approximates to the normal and the anisocytosis is small, the thickness of these cells.

The basis for an analysis of the results obtained for all the groups of C. glareolus examined were the mean values of blood indices. The sets from which these means were calculated were characterized by their confidence intervals. An adequately narrow confidence interval indicates that the number of animals is sufficient and the mean value representative of the given group. The means were examined by Student's $t$ test. The normal range of fluctuations of blond indices in laboratory animals determined the confidence interval for particular observations $(\overline{\mathrm{x}} \pm \tau \cdot \mathbf{S})$. Analyses of the data from the annual cycles included comparisons of the minimum and maximum values of indices, using Tukey's test to find which of them undergo seasonal fluctuations. The correlation between particular blood indices examined and the age of bank voles was defined by drawing regression lines. The significance of deviation of these lines from the axis representing the scale of age was checked by the $t$ test.

III. NORMAL VALUES OF MORPHOLOGICAL INDICES OF BLOOD OF C. GLAREOLUS AS COMPARED WITH THOSE OF OTHER LABORATORY MICROTIDAE

Mean values of blood indices of $C$. glareolus were calculated separately for males and females. Since these values do not differ statistically, common means were found for laboratory bank voles irrespective of sex ('Table 1). The small confidence intervals, not larger than the admissible

Table 1.

Morphological indices of blood of adult C. glareolus under laboratory conditions. (Mean values and confidence intervals).

\begin{tabular}{|c|c|c|c|c|c|c|c|}
\hline Index & $\begin{array}{l}M a 103 \\
/ D=16 /\end{array}$ & $\begin{array}{l}\text { Poocalos } \\
/ \mathrm{n}-16 /\end{array}$ & $\begin{array}{l}\text { Males a } \\
\text { Pomales } \\
/ D=32 /\end{array}$ & $\begin{array}{l}\text { Pregnant } \\
\text { feomles } \\
/ \mathrm{n}=10 /\end{array}$ & $\begin{array}{l}\text { D1fP. } \\
4: 2\end{array}$ & $\begin{array}{l}\text { Laotating } \\
\text { fomalos } \\
/ \mathrm{n}=10 /\end{array}$ & $\begin{array}{l}\text { D1fP. } \\
6: 2\end{array}$ \\
\hline & 1 & 2 & 3 & 4 & 5 & 6 & 7 \\
\hline Ho. $8^{x}$ & $17.2 \pm 0.9$ & $17.1 \pm 0.7$ & $17.2 \pm 0.3$ & $16.0 \pm 0.4$ & + & $15.7 \pm 0.9$ & + \\
\hline$R B C$, m11110n & $12.42 \pm 0.69$ & $12.67 \pm 0.70$ & $12.55 \pm 0.47$ & $10.52 \pm 1.30$ & + & $9.77 \pm 0.99$ & + \\
\hline $\mathrm{MCH}, \gamma \gamma$ & $14.0 \pm 0.5$ & $13.6 \pm 1.0$ & $13.8 \pm 0.3$ & $15.4 \pm 1.2$ & + & $16.2 \pm 1.0$ & + \\
\hline Baematocrit & $47.3 \pm 1.4$ & $46.4 \pm 1.8$ & $46.8 \pm 1.4$ & $42.0 \pm 3.2$ & + & $42.0 \pm 2.8$ & + \\
\hline RSC D1am. u & $5.11 \pm 0.10$ & $5.08 \pm 0.10$ & $5.10 \pm 0.11$ & $5.21 \pm 0.16$ & + & $5.34 \pm 0.16$ & + \\
\hline RBC Vol. $\mu^{3}$ & $38.4 \pm 2.0$ & $36.8 \pm 2.1$ & $37.6 \pm 1.5$ & $40.4 \pm 2.8$ & - & $43.5 \pm 4.0$ & + \\
\hline $\begin{array}{l}\text { RBC } \\
\text { Th1 okoess } \mu\end{array}$ & $1.88 \pm 0.10$ & $1.82 \pm 0.09$ & $1.85 \pm 0.07$ & $1.91 \pm 0.10$ & - & $1.94 \pm 0.18$ & - \\
\hline $\mathrm{MCHC} \$$ & $36.4 \pm 1.3$ & $37.0 \pm 1.3$ & $36.7 \pm 0.9$ & $38.1 \pm 2.0$ & - & $37.4 \pm 2.2$ & - \\
\hline
\end{tabular}

measuring and calculation errors, give evidence of little individual variation of the values examined and allow us to consider the means to be representative of the laboratory bank voles. It was found that the anisocytosis was small and the distribution of measurements of the erythrocyte diameters approximated to the normal (Fig. 1). Thus, the average 
thickness calculated for a blood cell is not charged with a great error. 'This analysis permits the determination (by the formula $\overline{\mathrm{x}} \pm \tau \cdot \mathrm{S}$ ) of the normal range of fluctuations of the blood indices for this species (Table 2).

A comparison of these data with the values of indices obtained for other laberatory Microtidae (Table 2) leads to the statement that C. glareolus has a significantly higher haematocrit and haemoglobin level than the European pine vole Pitymys subterraneus (de S élys Long$\mathrm{ch}$ a $\mathrm{m} \mathrm{p} \mathrm{s}, 1835$ ) and Lagurus lagurus (P a $1 \mathrm{l}$ a s, 1773). Both these indices of the bank vole come near in magnitude to those found in the field vole Microtus agrestis (L inna e u s, 1761) and the common vole Microtus arvalis ( $\mathrm{Palla}$ s, 1779) (Tables 2, 3). The nearly equal $M C H C$ in all the

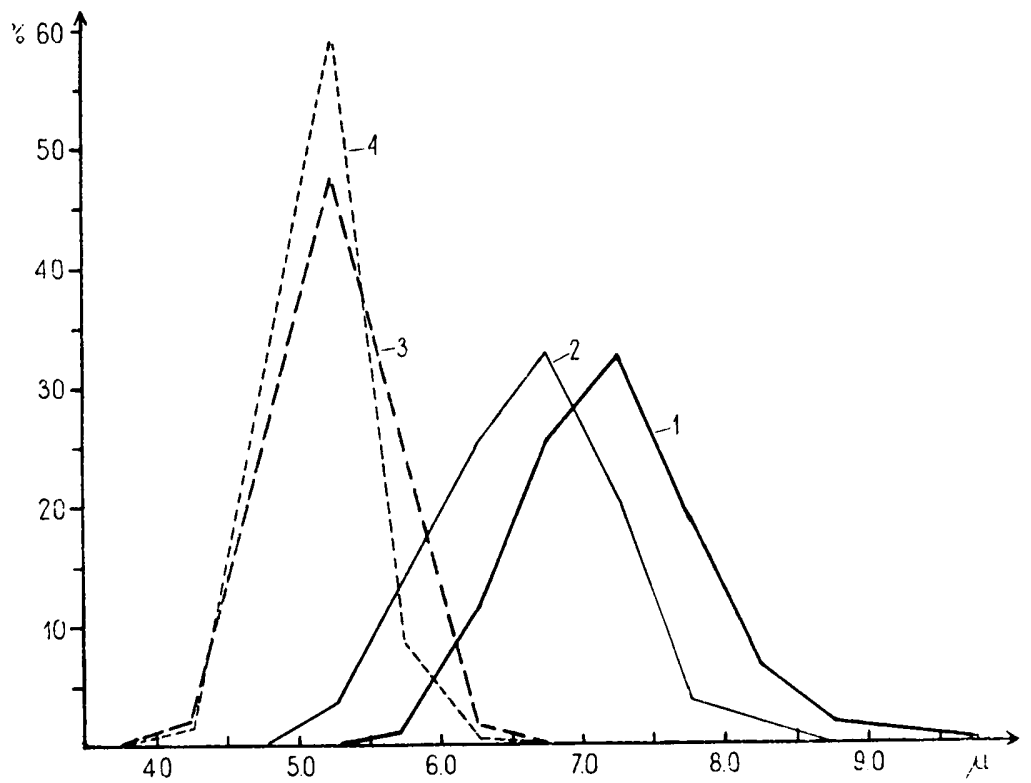

Fig. 1. Anisocytosis curves for selected age groups of C. glareolus.

$1-0-1$ day, $2-4-6$ days, $3-30-32$ days, $4-5-6$ months (standard).

Microtidae put to interspecific comparisons indicates that there is a directly proportional relation between the value of haematocrit and the $\mathrm{Hb}$ content in $100 \mathrm{ml}$. of blood. The similarity of haematocrit in $C$. glareolus and $M$. arvalis results from the similar number and size of their erythrocytes. There is no statistically significant difference between the $M C H$-s of these two species. Instead, the identical haematocrit in $C$. glareolus and $M$. agrestis are brought about by the smaller number of erythrocytes per $1 \mathrm{cu} . \mathrm{mm}$ of blood of the latter and the larger average $R B C$ volume owing to their actually larger thickness. The lower value of $M C H$ in $C$. glareolus than in $M$. agrestis is due to these correlations. The larger diameter and, what follows, the larger volume of erythrocytes 
in the European pine vole than in the bank vole account for the higher value of its haematocrit with the subequal number of blood cells in both these species. This is also why the $M C H$ of $C$. glareolus is larger than that of $P$. subterraneus. However, the higher value of haematocrit in the bank vole than in Lagurus lagurus must be explained, above all, by the larger number of erythrocytes, because their diameters and thicknesses do not differ significantly in these species. The difference between

Table 2.

Normal range of fluctuations in blood indices of $C$. glareolus and other laboratory Microtidae (* acc. to Kosteiecka-M y r cha, 1966a).

\begin{tabular}{|c|c|c|c|c|c|}
\hline Index & $\begin{array}{c}\text { Clethrlonomss } \\
\text { glareolus } \\
/ \mathrm{n}=32 /\end{array}$ & $\begin{array}{l}\text { Lucrotus. } \\
\text { agrest1s } \\
/ n=30 /\end{array}$ & $\begin{array}{l}\text { Miorotus } \\
\text { arval1s } \\
/ n=27 /\end{array}$ & $\begin{array}{l}\text { P1tymgs } \\
\text { subterraneus } \\
/ \mathrm{n}=30 /\end{array}$ & $\begin{array}{l}\text { Lagurus } \\
\text { lagurus } \\
/ n=42 /\end{array}$ \\
\hline Hb. $E^{5}$ & $17.2 \pm 1.5$ & $16.8 \pm 1.8$ & $16.0 \pm 4.3$ & $16.0 \pm 1.9$ & $14.8 \pm 3.1$ \\
\hline ABC, $11110 \mathrm{n}$ & $12.5 \pm 2.5$ & $11.3 \pm 2.2$ & $11.9 \pm 3.5$ & $13.0 \pm 2.1$ & $11.6 \pm 2.1$ \\
\hline $\mathrm{xCH}, \gamma 8$ & $13.8 \pm 2.9$ & $14.9 \pm 3.0$ & $13.7 \pm 4.1$ & $12.3 \pm 1.4$ & $12.8 \pm 2.9$ \\
\hline Heomatoorit 4 & $46.8 \pm 7.3$ & $46.3 \pm 7.6$ & $44.2 \pm 9.7$ & $43.9 \pm 8.5$ & $41.7 \pm 7.3$ \\
\hline RBC D1AR. $\mu$ & $5.10 \pm 0.2$ & $3.04 \pm 0.3$ & $5.10 \pm 0.3$ & $4.87 \pm 0.4$ & $5.08 \pm 0.4$ \\
\hline BBC $V_{01} \cdot \mu^{3}$ & $37.6 \pm 7.8$ & $41.1 \pm 7.9$ & $37.7 \pm 12.0$ & $33.7 \pm 7.4$ & $36.0 \pm 5.3$ \\
\hline RBC Thlokness $\mu$ & $1.85 \pm 0.4$ & $2.07 \pm 0.5$ & $1.50 \pm 1.1$ & $1.81 \pm 0.4$ & $1.79 \pm 0.4$ \\
\hline MCBC $\%$ & $36.9 \pm 4.9$ & $36.3 \pm 5.5$ & $36.6 \pm 6.5$ & $36.6 \pm 5.6$ & $35.8 \pm 3.4$ \\
\hline
\end{tabular}

Table 3.

Comparison of the values of blood indices in C. glareolus with those in other laboratory Microtidae.

\begin{tabular}{|c|c|c|c|c|c|c|c|c|}
\hline Species & $\underset{B d}{H b .}$ & $\begin{array}{c}\mathrm{RBC} \\
\text { mill1ion }\end{array}$ & $\begin{array}{l}\text { MCH } \\
\gamma \gamma\end{array}$ & $\begin{array}{l}\text { Haema- } \\
\text { toor1t } \\
\%\end{array}$ & $\begin{array}{c}\mathrm{RBC} \\
\text { D1 am. } \mu\end{array}$ & $\begin{array}{c}\stackrel{\mathrm{RBC}}{3} \\
\text { Vo1. } \mu^{3}\end{array}$ & $\begin{array}{c}\mathrm{RBC} \\
\operatorname{Tn} 1 \text { clness } \\
\mu\end{array}$ & $\underset{x}{\mathrm{MCHC}}$ \\
\hline 4. agrest1s & - & + & + & - & - & + & + & - \\
\hline M. arval1s & + & - & - & $+^{*}$ & - & - & - & - \\
\hline P. subterraneus & + & - & + & + & + & + & - & - \\
\hline I. lagurus & + & + & + & + & - & + & - & - \\
\hline
\end{tabular}

$\uparrow=$ statistically significant, $-=$ statistically not significant, ${ }^{*}$ ) at 0.01 differences not significant.

the volumes of erythrocytes may result from an error with which all the indices calculated, and not measured directly, are undoubtedly charged. The $M C H$ has also a higher value in C. glareolus than in L. lagurus.

To sum up, the bank vole as compared with other Microtidae is characterized by a higher level of haemoglobin and, at the same time, has as large an $R B C$ number as $P$. subterraneus has but the diameter of 
erythrocytes of the former is larger, as large as that in the remaining species examined. Thus, the morphological picture of blood shows that C. glareolus has exceptionally good conditions, which enable it to maintain the function of haemoglobin at a relatively high level under laboratory conditions.

\section{BLOOD INDICES DURING PREGNANCY AND LACTATION}

Ten laboratory females in the final stage of pregnancy $(19$ th $-21 \mathrm{st}$ day) and 10 others during the first 4 days of lactation were examined (Table 1, lines 4 and 6 ). The values of all the blood indices in both these groups du not show any statistically significant differences. The confidence intervals are larger than those calculated while the normal variation of blood indices was being determined, but they seem sufficiently small for the means to be compared. The small anisocytosis (Fig. 2)

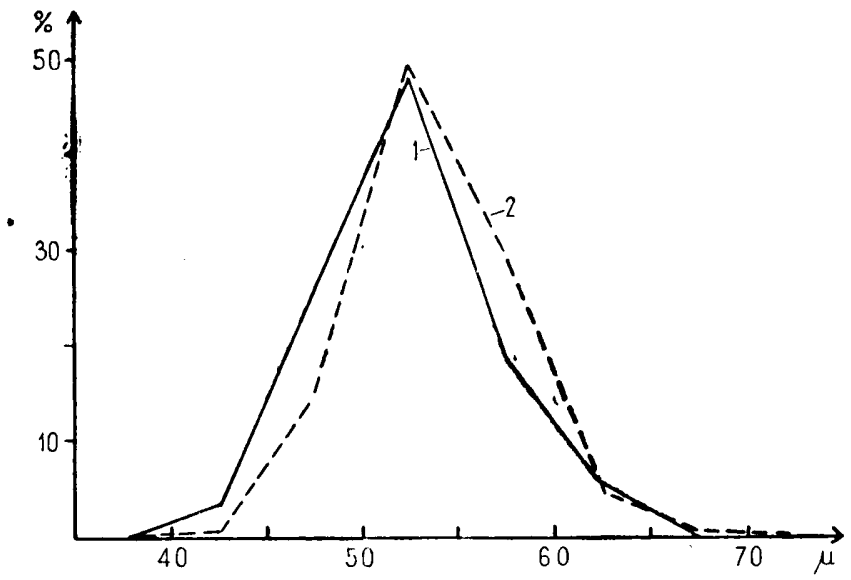

Fig. 2. Anisocytosis curves of pregnant (1) and lactating (2) females of C. glareolus.

allows the calculation of the thickness of blood cells on the basis of their average diameter. The haematocrit and the level of haemoglobin in pregnant and lactating females have statistically significantly lower values than the standard value established (Table 1). These values drop proportionally to each other, as evidenced by the value of $M C H C$, which does not differ from the standard. The lower value of haematocrit in the females examined is caused by a considerable decrease in the number of erythrocytes per $1 \mathrm{cu}$. $\mathrm{mm}$ of blood, because the diameter of erythrocytes is significantly larger and even brings about a statistically significant increase in the average $R B C$ volume. The number of erythrocytes decreases so much that despite the simultaneous lowering of the haemoglobin level the value of $M C H$ is significantly higher in pregnant and lactating females than the standard. Thus, we may assume that in the 
final period of pregnancy and during the first days of lactation the morphological picture of blood in female C. glareolus shows changes, which contribute much to the reduction in the function of haemoglobin.

\section{VARIATION OF MORPHOLOGICAL INDICES OF BLOOD IN THE POSTNATAL DEVELOPMENT}

The highest level of haemoglobin was found in newly born animals (Fig. 3). It, however, begins to lower at once and reaches its minimum as early as the 6 th or 7 th day. Then the $H b$ content per $100 \mathrm{ml}$. of blood increases up to about the 30 th day of life. From that moment onwards, this index does not change with age of animals any more. The drop in the $\mathrm{Hb}$ level, taking place from the 2 nd to the 7 th day of life, proceeds much more rapidly than the following rise, which takes more than 20 days and does not reach such values as are observed immediately after birth.

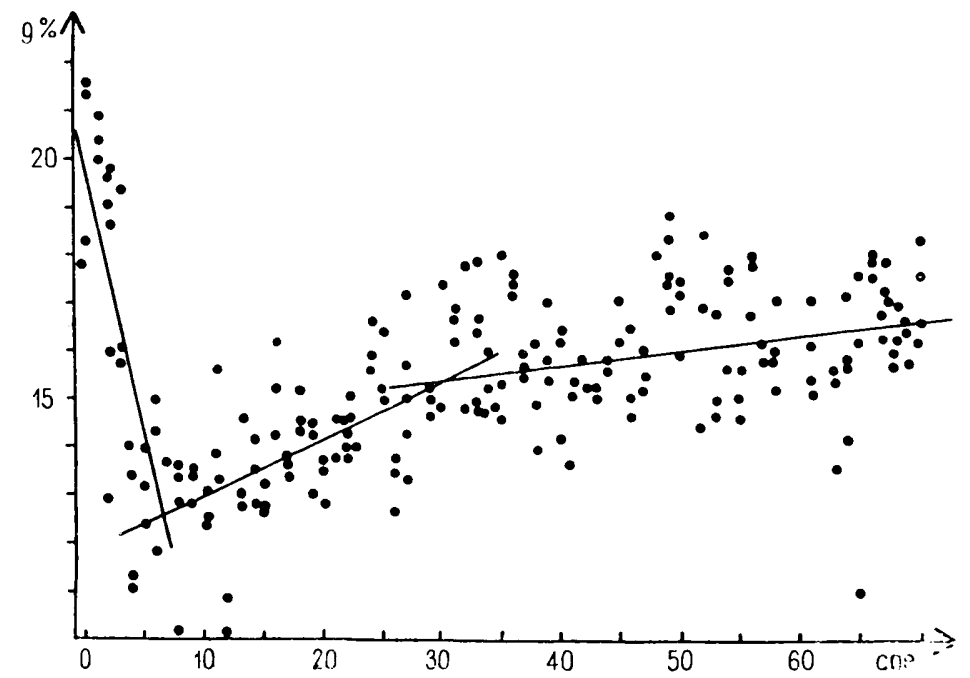

Fig. 3. Variation in the $\mathrm{Hb}$ content $(\mathrm{g} / 100 \mathrm{ml}$ ) during the postnatal development of C. glareolus.

The variation of the values of haematocrit in the postnatal development of C. glareolus presents itself quite similarly (Fig. 4). This value is also established about the 30th day and, though it is also lower than that found after birth, yet it does not differ from this last significantly (Tables 4 and 5). Generally, however, the variation of the haemoglobin level and haematocrit are directly proportional. Owing to this the MCHC does not practically change throughout the life of animals under study. (Fig. 5, Tables 4 and 5).

The number of erythrocytes decreases during the first days of the postnatal development, then it increases up to the 30 th day not to change 


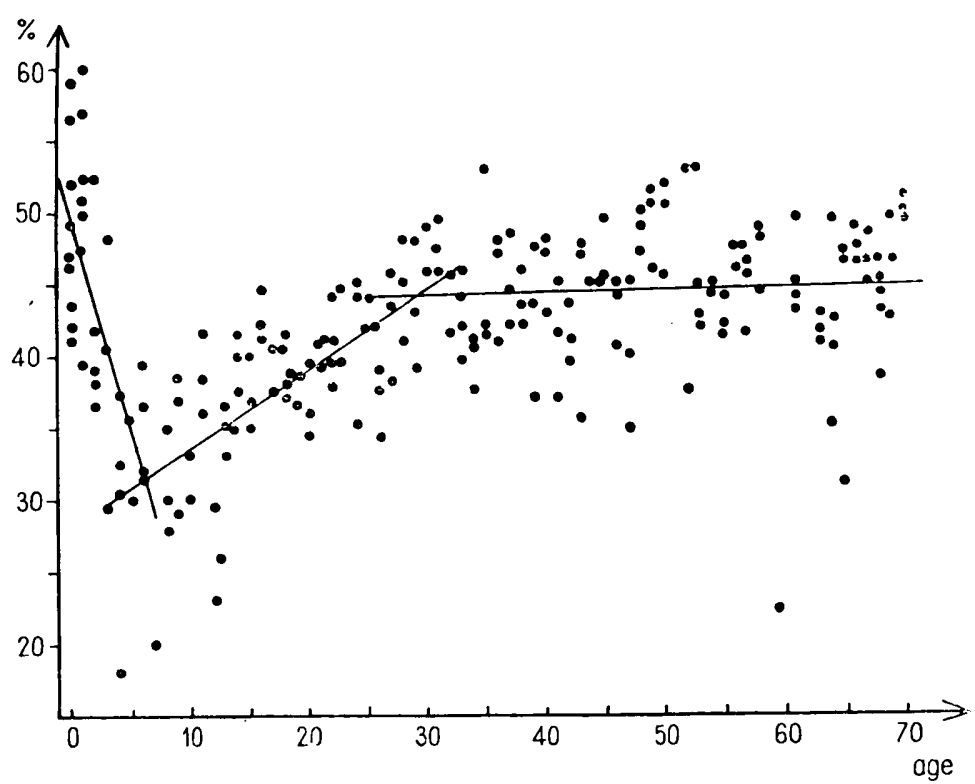

Fig. 4. Variation in the value of haematocrit during the postnatal development of

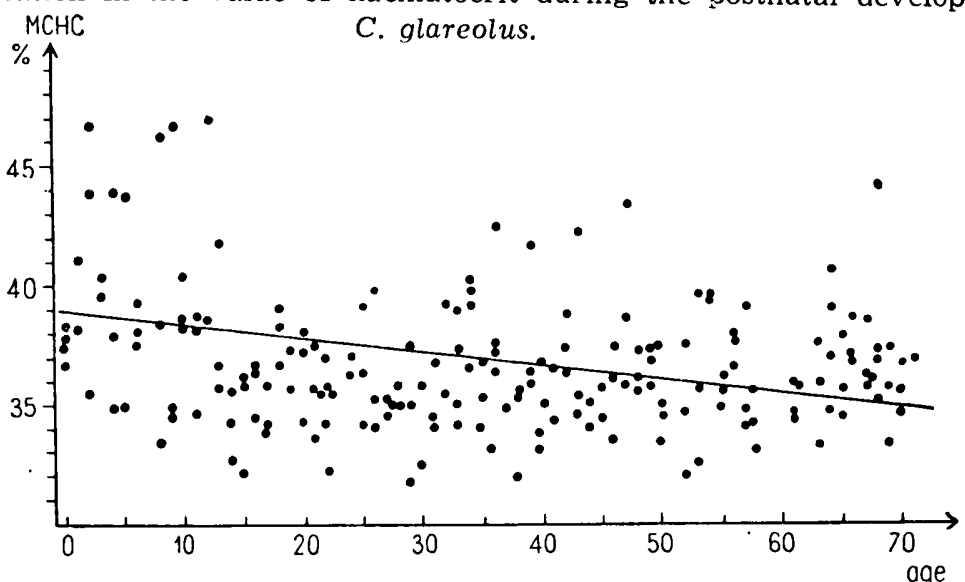

Fig. 5. Variation of $M C H C$ during the postnatal development of C. glareolus.

with age any more (Fig. 6). The initial drop in the $R B C$ number, though statistically significant, is not very great compared with the rise which follows it (Tables 4 and 5). As the $R B C$ diameter also decreases at the same time (Fig. 7), the very great decrease in the haematocrite is quite natural. The relatively intense increase of this index in the next period, lasting up to about the 30th day of postnatal development, is brought about by a very great rise in the number of erythrocytes, because at the same time their diameter decreases. Approximately from the 30th day the $R B C$ diameter does not change any more (Tables 4 


\section{Table 4.}

Morphological indices of blood for selected age groups of C. glareolus. (Mean values and confiderice intervals).

\begin{tabular}{|c|c|c|c|c|}
\hline \multirow{2}{*}{ Index } & \multicolumn{4}{|c|}{ 1ge / In days/ } \\
\hline & $\begin{array}{l}0=1 \\
/ n=22 /\end{array}$ & $\begin{array}{l}4=6 \\
/ 2=10 /\end{array}$ & $\begin{array}{l}30=32 \\
/ n=7 /\end{array}$ & $\begin{array}{l}68=70 \\
/ n=10 /\end{array}$ \\
\hline Ho. $e^{x}$ & $20.0 \pm 2.0$ & $13.0 \pm 1.2$ & $16.4 \pm 0.8$ & $16.7 \pm 1.0$ \\
\hline$R B C, 11110 \mathrm{n}$ & $5.33 \pm 0.38$ & $4.12 \pm 0.61$ & $10.93 \pm 0.89$ & $11.52 \pm 0.91$ \\
\hline$\triangle I C A, \quad \gamma \gamma$ & $37.6 \pm 4.9$ & & $15.0 \pm 1.5$ & $14.6 \pm 0.9$ \\
\hline Hedeatocrit $\%$ & $49.6 \pm 3.5$ & $32.3 \pm 3.0$ & $46.3 \pm 3.3$ & $45.9 \pm 3.3$ \\
\hline RBC D1an. $\mu$ & $7.13 \pm 0.12$ & & $5.22 \pm 0.24$ & $3.11 \pm 0.04$ \\
\hline RBC $V_{01} \cdot \mu^{3}$ & $93.6 \pm 6.0$ & & $42.5 \pm 2.2$ & $40.1 \pm 2.9$ \\
\hline RBC Th1 ckoless $u$ & $2.33 \pm 0.12$ & & & $1.97 \pm 0.15$ \\
\hline $\operatorname{Mcac} \varnothing$ & $38.2 \pm 0.9$ & & & $36.6 \pm 2.1$ \\
\hline
\end{tabular}

Table 5.

Comparison of the values of blood indices of the selected age groups of C. glareolus. $+=$ statistically significant, $-=$ statistically not significant, I $-0-1$ day, II 4--6 days, III $-30-32$ days, IV $-68-70$ days, V $-5-6$ months (standard).

\begin{tabular}{|c|c|c|c|c|c|c|c|c|}
\hline $\begin{array}{l}\text { AEe groups } \\
\text { compared: }\end{array}$ & $\begin{array}{l}\mathrm{Hb} . \\
\mathrm{g} \&\end{array}$ & $\begin{array}{c}\mathrm{RBC} \\
\text { mililion }\end{array}$ & $\begin{array}{l}\mathrm{MCR} \\
\gamma \gamma\end{array}$ & $\begin{array}{l}\text { Haema- } \\
\text { tocr1t } \\
\&\end{array}$ & $\begin{array}{c}\mathrm{RBC} \\
\mathrm{D1am} \cdot \mu\end{array}$ & $\begin{array}{l}\text { RBC } \\
\text { Vol. } \\
\mu^{3}\end{array}$ & $\begin{array}{c}\text { RBC } \\
\text { Thickness } \\
\mu\end{array}$ & $\underset{x}{\mathrm{MCHC}}$ \\
\hline$I$ - II & + & + & & + & & & & \\
\hline$I I-I I I$ & + & + & & + & & & & \\
\hline$I-I I I$ & + & + & + & - & + & + & & \\
\hline$I I I-I V$ & - & - & - & - & - & - & & \\
\hline$I V-V$ & - & - & - & - & - & - & - & - \\
\hline
\end{tabular}

and 5). Anisocytosis, generally small in C. glareolus, becomes very small from that moment (Fig. 1). The average volume of erythrocytes changes very similarly to their diameter (Fig. 8, Tables 4 and 5), because the thickness of erythrocytes, which undergoes no statistically significant changes with age (Fig. 9, Tables 4 and 5), cannot modify the value of this index. As a result of the above-presented correlations, the $\mathrm{MCH}$ decreases to about the 20th day of postnatal development, then it soon becomes established and does not change in the next period (Fig. 10, Tables 4 and 5). 


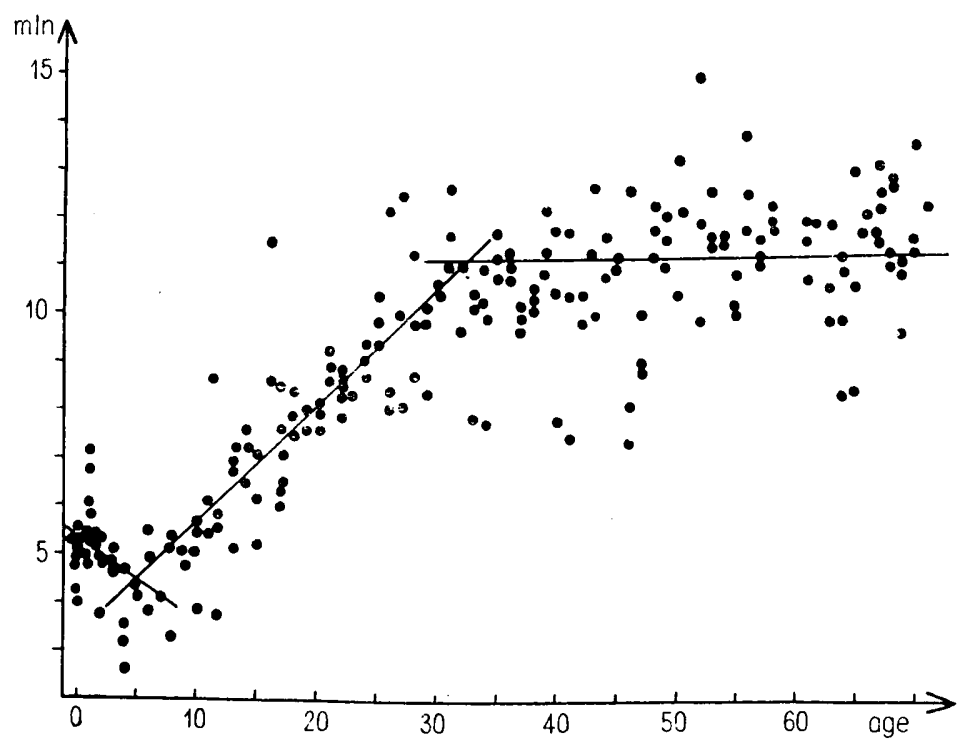

.Fig 6. Variation of the number of erythrocytes per 1 cu.mm of blood during the postnatal deveiopment of C. glareolus.

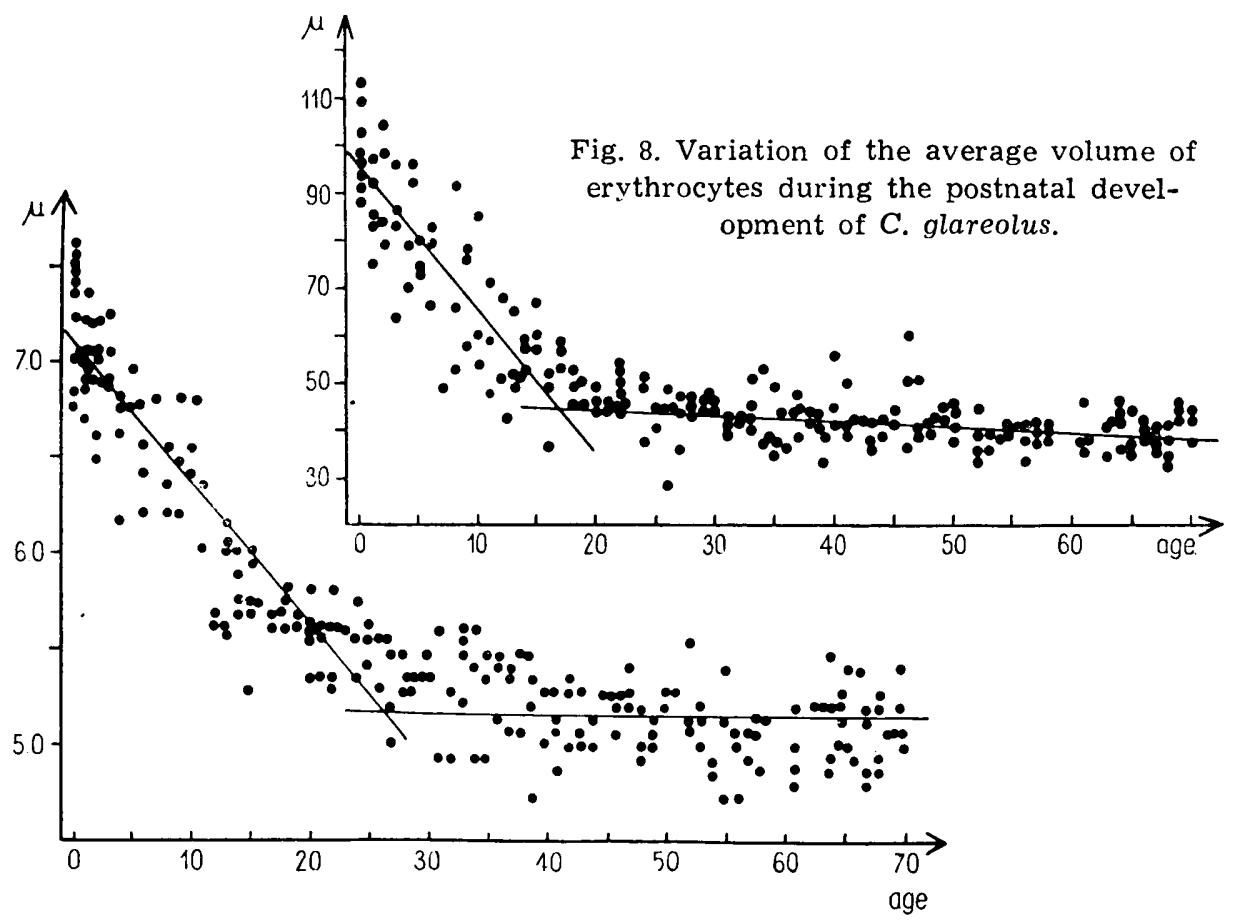

Fig. 7. Variation of the mean diameter of erythrocytes during the postnatal development of C. glareolus. 


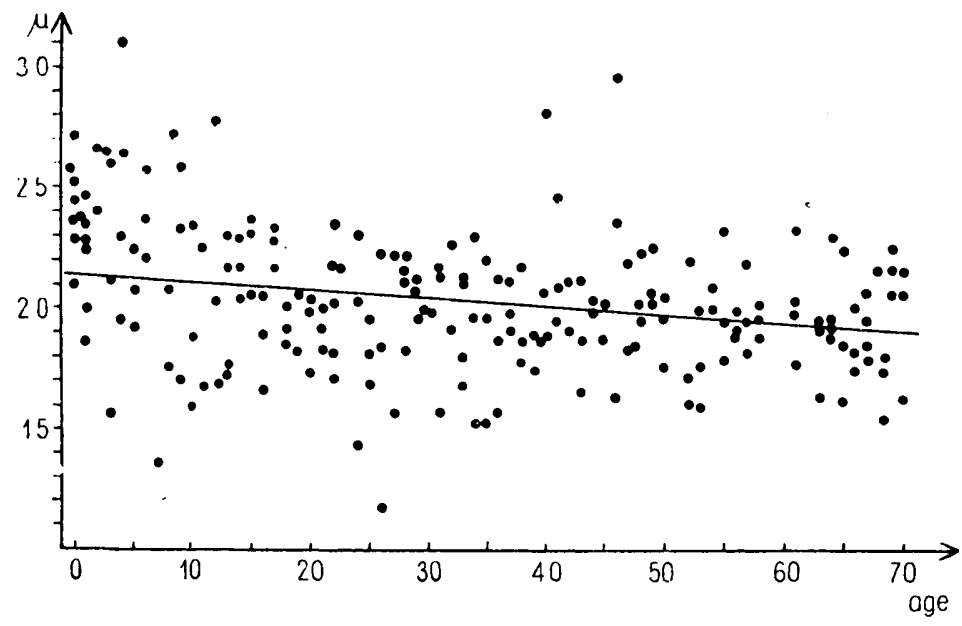

Fig. 9. Variation of the average thickness of erythrocytes during the postnatal

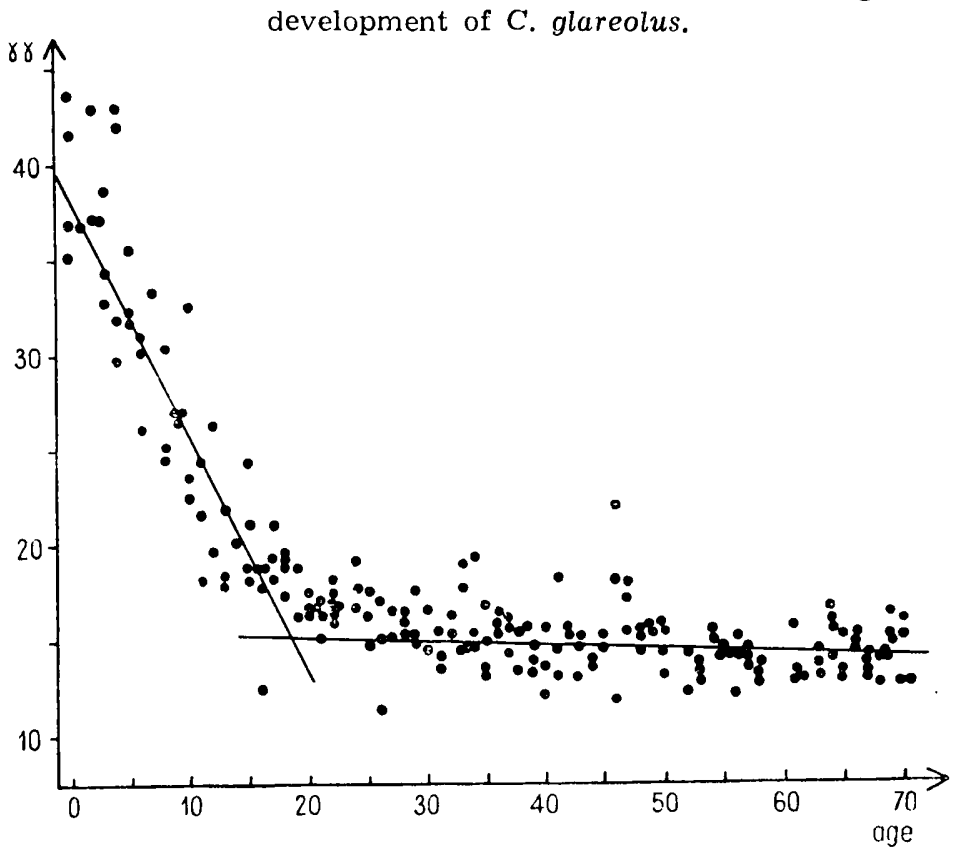

Fig. 10. Variation of $M C H$ during the postnatal development of C. glareolus.

Apart from the fact that postnatal anaemia was observed in some dozens of bank voles - it was symptomatized, above all, by a rapid lowering of the level of $\mathrm{Hb}$ - it may be stated that the changes which occur in the postnatal development of this species and result in an increase of the total surface area of erythrocytes enhance the function of haemoglobin. 
As the data arranged separately for either sex showed that the variation of the morpholocigal picture of blood with age presents itself identically for males and females of $C$. glareolus, all the results were analysed together irrespective of the sex of specimens.

\section{SEASONAL VARIATION}

Studies were carried out from June 1964 to June 1965. The results presented in this paper make it possible to disregard the age of specimens examined in the analyses of seasonal variation in the morphological picture of blood of C. glareolus. On the other hand, pregnant and lactating females, which would have lowered the values of indices significantly in spring and summer, were excluded from the material for study. The resulting unequal sex composition of the samples examined did not influence the results obtained, because $C$. glareolus does not show sexual dimorphism in the morphological picture of blood. No statistically significant differences were also found between the active and inactive males caught in February-March 1965.

The confidence intervals calculated for each index and each month indicate that the number of specimens was sufficient for us to regard the monthly means as representative (Table 6).

Small anisocytosis and the distribution of $R B C$ diameter in animals from particular months (Table 7), approximating to the normal, allowed the use of the average size of blood cells to calculate other indices.

A comparison of the minimum and maximum values of each index shows that only the thickness of erythrocytes and the $M C H C$ are unchangeable in the annual cycle. The lowest level of haemoglobin and the smallest haematocrit are observed in August. In the autumn the values of both these indices increase. In the winter the quantity of $\mathrm{Hb}$ and haematocrit maintain their high values and in the spring their further growth takes place till they reach their maxima in April (Fig. 11). Owing to the parallel course of changes in the quantity of $\mathrm{Hb}$ and the value of haematocrit, the $M C H C$ does not fluctuate in the annual cycle significantly (Fig. 11). The fluctuations of haematocrit result frcm seasonal changes in the $R B C$ number and $R B C$ diameter, because the thickness of these blood cells shows no statistically significant differences in the annual cycle (Fig. 12). The smallest number of erythrocytes rer $1 \mathrm{cu} . \mathrm{mm}$ of blood occurs in June (Fig. 13). It increases during the next months to reach the maximum in December, keeps this high value till spring, when it begins to drop from March, and arrives at its minimum in June. In the course of seasonal changes in the number of erythrocytes attention is attracted by the fact that this number is inversely proportional to the seasonal fluctuations of temperature (Fig. 13). The fluctu- 
Table 6.

Seasonal variation of morphological indices of blood in C. glareolus. (Mean values and confidence intervals).

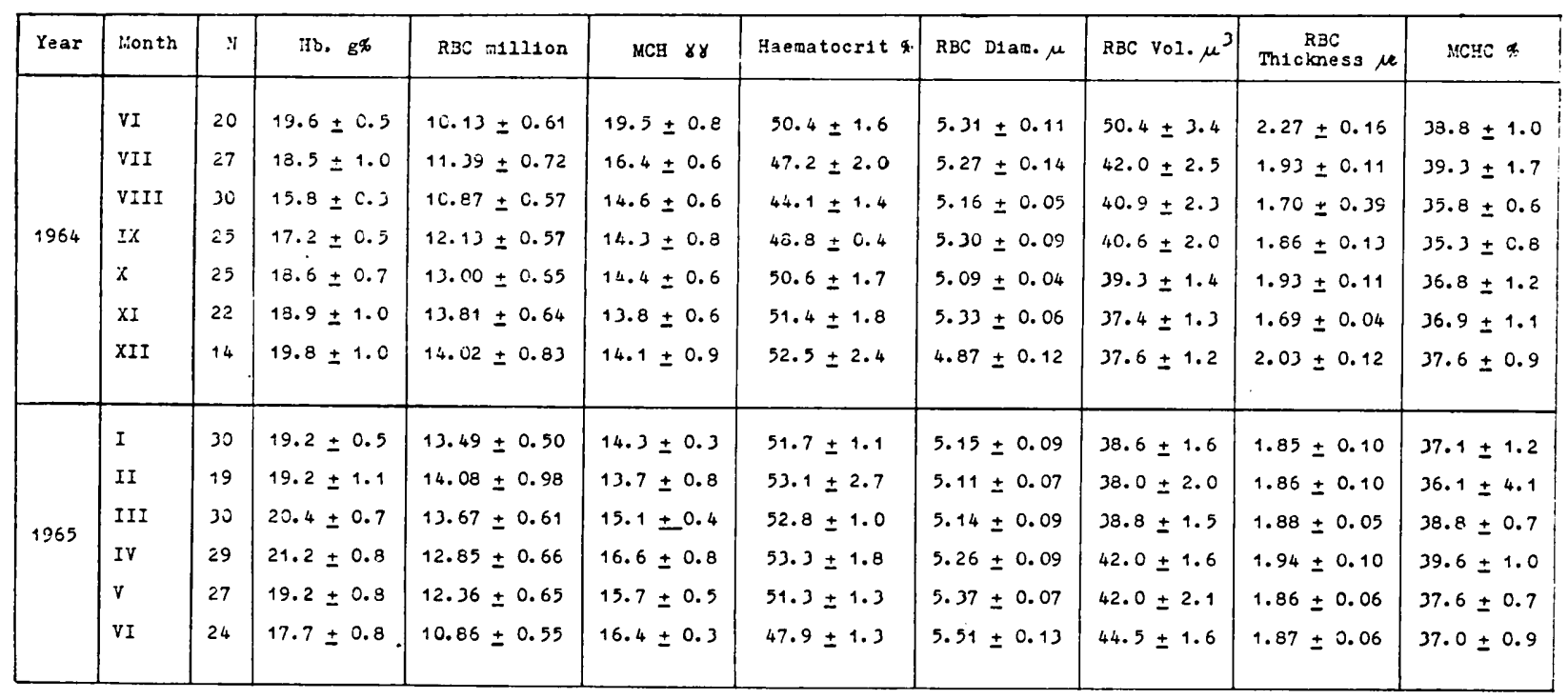


Table 7.

Seasonal variation of the distribution of erythrocyte diameters (in \%).

\begin{tabular}{|c|c|c|c|c|c|c|c|c|}
\hline Year & Yonth 8 & $3.50-$ & $4.00-$ & $4.50-$ & $5.00-$ & $5.50-$ & $6.00-$ & $6.30-$ \\
\hline 1964 & $\begin{array}{l}\text { VI } \\
\text { VII } \\
\text { VIII } \\
\text { IX } \\
X \\
\text { XI } \\
\text { XII }\end{array}$ & $\begin{array}{l}0.1 \\
1.6 \\
0.4\end{array}$ & $\begin{array}{r}1.0 \\
2.5 \\
2.5 \\
4.5 \\
3.1 \\
1.4 \\
13.4\end{array}$ & $\begin{array}{l}18.5 \\
19.9 \\
26.0 \\
13.6 \\
32.9 \\
13.9 \\
44.8\end{array}$ & $\begin{array}{l}47.7 \\
32.2 \\
53.5 \\
44.1 \\
51.0 \\
49.9 \\
38.1\end{array}$ & $\begin{array}{r}25.7 \\
21.5 \\
17.2 \\
26.9 \\
12.1 \\
30.4 \\
3.3\end{array}$ & $\begin{array}{l}6.6 \\
3.8 \\
0.8 \\
8.1 \\
0.9 \\
4.2\end{array}$ & $\begin{array}{l}0.5 \\
1.1 \\
0.2\end{array}$ \\
\hline 1965 & $\begin{array}{l}\text { I } \\
\text { II } \\
\text { III } \\
\text { IV } \\
\text { V } \\
\text { VI }\end{array}$ & & $\begin{array}{l}1.5 \\
1.4 \\
1.0 \\
0.9 \\
0.4\end{array}$ & $\begin{array}{r}29.7 \\
28.2 \\
30.4 \\
17.1 \\
7.5 \\
6.1\end{array}$ & $\begin{array}{l}55.0 \\
59.4 \\
57.6 \\
58.9 \\
53.0 \\
41.0\end{array}$ & $\begin{array}{l}13.1 \\
10.7 \\
10.2 \\
21.4 \\
35.6 \\
36.2\end{array}$ & $\begin{array}{r}0.6 \\
0.2 \\
0.7 \\
1.7 \\
3.9 \\
13.7\end{array}$ & 2.5 \\
\hline
\end{tabular}

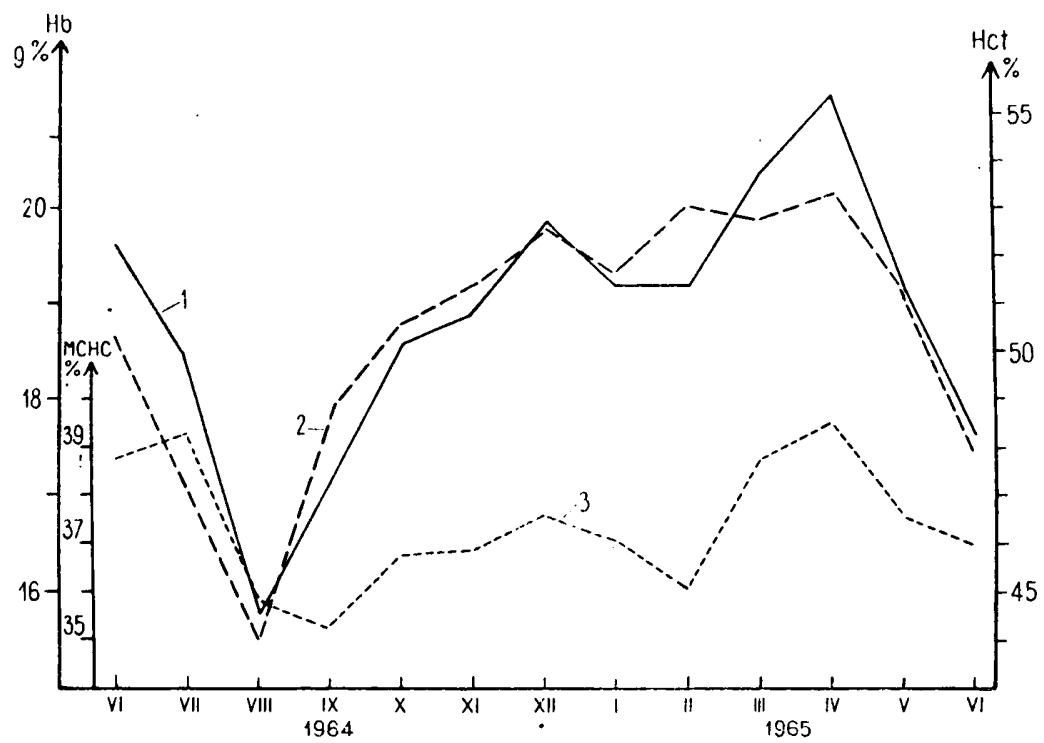

Fig. 11. Seasonal variation of blood indices in C. glareolus.

1 - Hb content, 2 - haematocrit, $3-M C H C$.

ations of the diameter of blood cell proceed contrariwise, i.e., they are the smallest in December and the largest in June (Fig. 12). The length of day seems to play a decisive role in the controlling of this process. The changes in the average volume of blood cells proceed in a similar manner, because statistically they are dependent only upon the changes in the diameter (Fig. 12). 


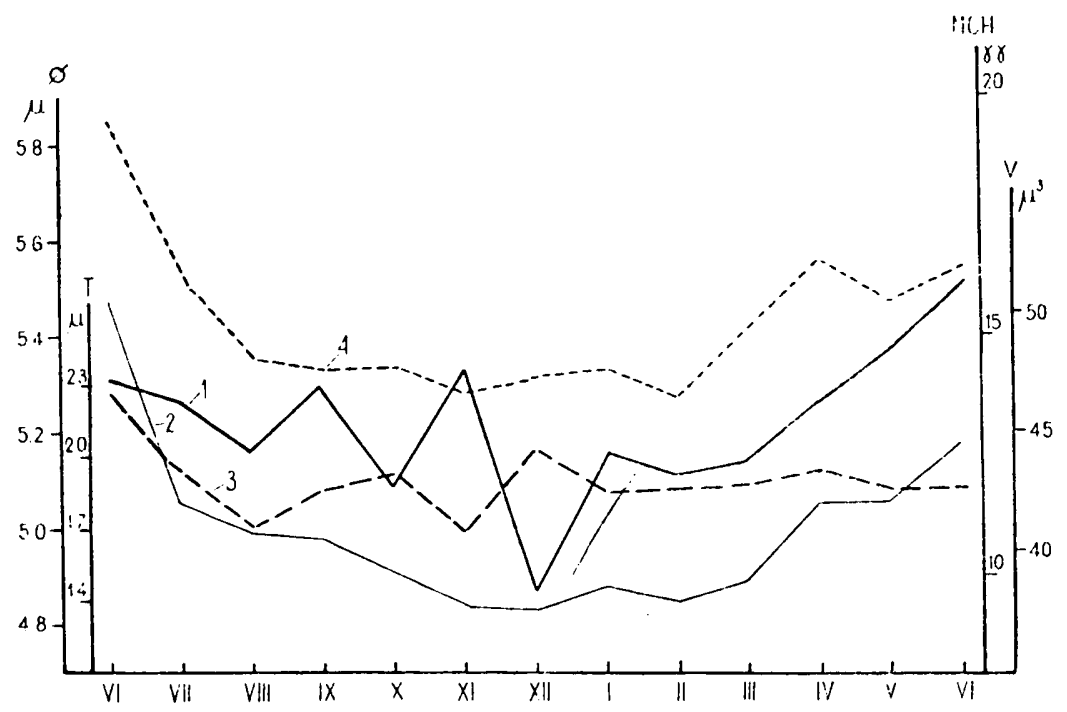

Fig. 12. Seasonal variation of blood indices in C. glareolus.

1 - diameter of erythrocytes, 2 - volume of erythrocytes, 3 - thickness of erythrocytes, $4-M C H$.

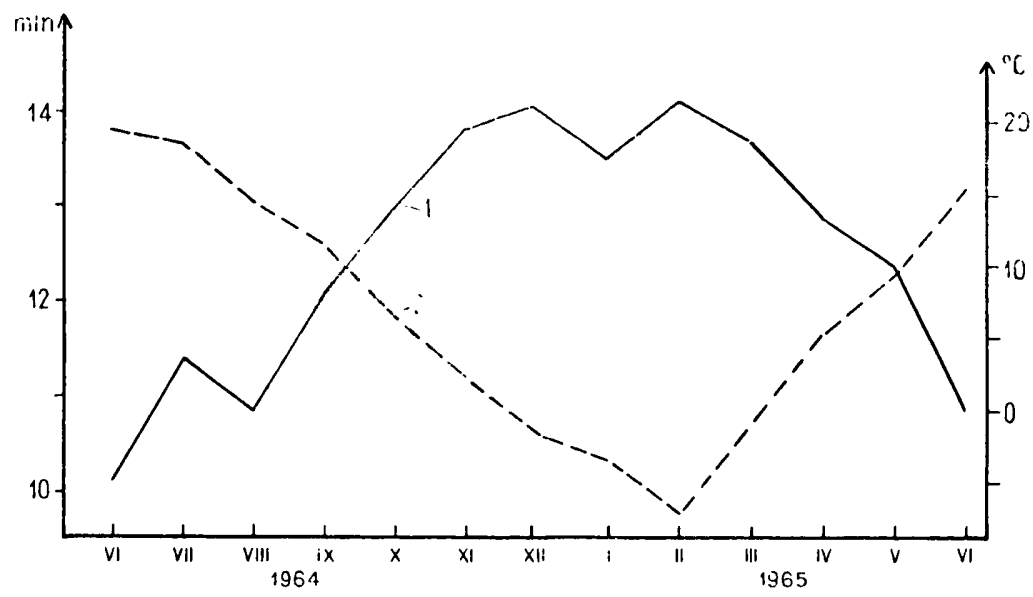

Fig. 13. Seasonal fluctuation of the number of erythrocytes per 1 cu.mm of blood of C. glareolus (1) and that of ambient temperature (2).

The minimum value of haematocrit, which occurs in August, may thus be explained by the fact that the number of erythrocytes, though being on the increase, is still comparatively small and at the same time the average volume of particular erythrocytes decreases remarkably as compared with its June value. The further decrease in the volume of crythrocytes proceeds less intensely, whereas their number increases 
very distinctly, which brings about a rise in the haematocrit value. The spring growth of this index is due to the still large, though already decreasing, number of erythrocytes and their distinctly larger volume. Next, in spite of the further growth in size of the blood cells, the value of haematocrit drops rapidly, because the number of cells decreases rapidly. As a result of all these changes, the $M C H$ is highest in June; then it decreases to reach the minimum in the winter and begins to rise again in the spring (Fig. 12).

On the basis of the here presented correlations it may be stated that the relatively large content of $H b$ in blood and the very large total surface of erythrocytes ensure the high level of haemoglobin function indispensable to C. glareolus in the winter. On the other hand, in the spring the quantity of haemoglobin still increases and despite the somewhat smaller number of erythrocytes the haematocrit is proportionally larger, owing to the increase in size of $R B C$.

\section{THE EFFECT OF DAY LENGTH AND TEMPERATURE ON THE MORPHOLOGICAL PICTURE OF BLOOD}

The animals collected in the Białowieża National Park towards the end of November 1964 were divided into 3 groups, containing 30 specimens each, and kept in pairs in cages under different thermal and light conditions. They were all offered the same food in excess. Group $A$

\section{Table 8.}

Morphological indices of blood of C. glareolus under different thermal and light conditions (Mean values and confidence intervals). $\mathrm{A}-0^{\circ} \mathrm{C}, 6$-hour day, $\mathrm{B}-22^{\circ} \mathrm{C}$, 6 -hour day, $\mathrm{C}-22^{\circ} \mathrm{C}, 18$-hour day.

\begin{tabular}{|c|c|c|c|}
\hline Index & $A / n=30 /$ & $\mathrm{B} / \mathrm{n}=30 /$ & $c / n=30 /$ \\
\hline Ho. 5 & $18.3 \pm 0.1$ & $17.6 \pm 0.5$ & $18.4 \pm 0.6$ \\
\hline RBC, w1110n & $14.11 \pm 0.56$ & $13.09 \pm 0.50$ & $12.99 \pm 0.70$ \\
\hline MCB, 88 & $13.1 \pm 0.5$ & $13.3 \pm 0.9$ & $14.2 \pm 0.6$ \\
\hline Haowatoorit & $49.5 \pm 1.3$ & $48.8 \pm 4.5$ & $50.1 \pm 1.5$ \\
\hline RBC D1am. $\mu$ & $4.59 \pm 0.09$ & $4.63 \pm 0.08$ & $4.84 \pm 0.12$ \\
\hline $\mathrm{RBC} \nabla 01 . \mu^{3}$ & $35.4 \pm 1.4$ & $37.3 \pm 1.4$ & $38.3 \pm 1.7$ \\
\hline RBC Th1okness $\mu$ & $2.15 \pm 0.08$ & $2.29 \pm 0.10$ & $2.09 \pm 0.10$ \\
\hline MCBC $\star$ & $37.0 \pm 0.5$ & $36.2 \pm 0.6$ & $36.6 \pm 1.1$ \\
\hline
\end{tabular}

was kept in an insulated room at a constant temperature of $0^{\circ} \mathrm{C}$. The day length was shortened by degrees from 8 to $6 \mathrm{hrs}$. Group $B$ first stayed at a room temperature for a few days and next the animals were moved to a room in which the constant temperature of $22^{\circ} \mathrm{C}$ was main- 
tained. The day length was shortened as for group $A$. Group $C$ - after a few initial days - was also placed at a temperature of $22^{\circ} \mathrm{C}$, but the day length was gradually lengthened up to $18 \mathrm{hrs}$. The animals were kept under so differentiated conditions for 10 weeks.

The confidence intervals incicate that the number of specimens was large enough for carrying out an analysis of differences between the mean values of particular blood indices (Table 8). The anisocitosis curves allow the use of the average $R B C$ diameter to calculate their thickness (Fig. 14).

The haemoglobin content of the blood of animals belonging to groups $A$ and $C$ is equal and relatively high (Table 8 ). If the conditions under which group $A$ was kept may be defined as winter conditions and the long day and high temperature which acted on the animals of group $C$

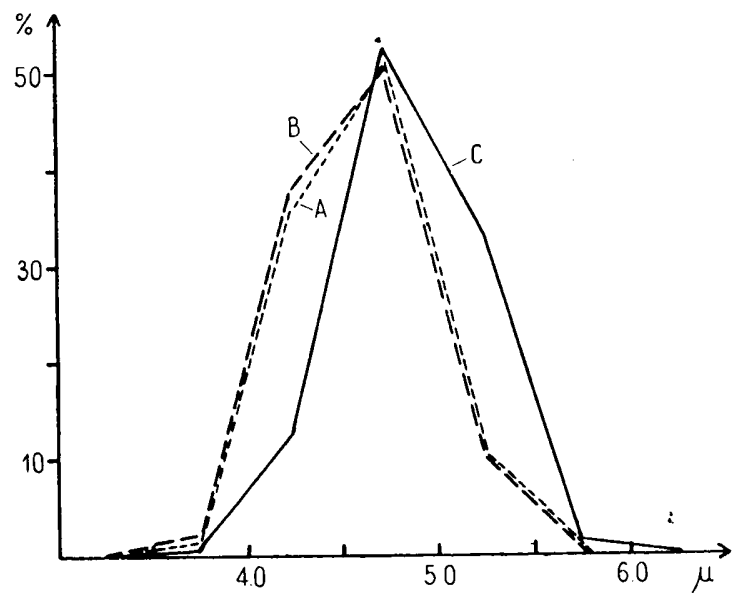

Fig. 14. Anisocytosis curves for C. glareolus under different thermal and light conditions. 1 - group A, 2 - group B, 3 - group C.

regarded as corresponding to sumer conditions, then it should be stated that the blood picture in both groups agrees with field observations. The inverse ratio of the number of erythrocytes to their average volume accounts for the value of haematocrit, which is subequal in all these groups of animals. This relation is not, however, complete, since the differences between the values of haematocrit, though statistically not significant, are great and corresponding to the differences in the $\mathrm{Hb}$ content to the extent that the $M C H C$ is almost equal in the animals of these groups (Table 9). We should take a similar view of the average thickness of erythrocytes, which is almost the same in the three groups and is not without effect on $R B C$ volume. This is manifested by the difference in $R B C$ volume between group $A$ and group $B$, whereas $R B C$ 
diameters are similar, and by the lack of such a difference between group $B$ and group $C$, which have different diameters of erythrocytes.

Most significant inferences arise from the consideration of differences in number and diameter of erythrocytes between the groups examined. The number of erythrocytes is almost equal only in the animals kept at the same temperature irrespective of day length. On the other hand, only the bank voles exposed to the action of days having identical lengths have nearly equal diameters of erythrocytes, which is independent of the

\section{Table 9.}

Comparison of the values of blood indices obtained for 3 experimental groups. $+=$ statistically significant, $-=$ statistically not significant, $\mathrm{A}-0^{\circ} \mathrm{C}, 6$-hour day, $\mathrm{B}-22^{\circ} \mathrm{C}, 6$-hour day, $\mathrm{C}-22^{\circ} \mathrm{C}, 18$-hour day.

\begin{tabular}{|c|c|c|c|c|c|c|c|c|}
\hline Groups & $\begin{array}{l}\text { Hb. } \\
E x\end{array}$ & $\begin{array}{c}\text { RRC } \\
\text { m11110n }\end{array}$ & $\begin{array}{c}\mathrm{MCH} \\
\gamma \gamma\end{array}$ & $\begin{array}{l}\text { Haema- } \\
\text { tocrit } \\
\$ \neq\end{array}$ & $\begin{array}{c}\mathrm{RBC} \\
\mathrm{Di} \mathrm{am} . \\
\mu\end{array}$ & $\begin{array}{l}\text { RBC } \\
\text { Vol. } \\
\mu^{3}\end{array}$ & $\begin{array}{c}\text { RBC } \\
\text { Thickness } \\
\mu\end{array}$ & $\underset{\nexists}{\mathrm{WCH}}$ \\
\hline$A-B$ & + & + & - & - & - & + & - & - \\
\hline$A-C$ & - & + & + & - & + & + & - & - \\
\hline$B-C$ & + & - & - & - & + & - & - & - \\
\hline
\end{tabular}

fact whether the temperatures are the same or not (Table 9). These data suggest that the mechanism observed in the annual cycle is controlled by day length, which has an effect on the size of erythrocytes, and by temperature, which is responsible for their number.

\section{MORPHOLOGICAL INDICES OF BLOOD OF A HIGHLAND POPULATION}

The material was collected in the region of the upper boundary of the range of $C$. glareolus in the Tatra $M$ ts. and for this reason it is relatively poor. After all, the confidence intervals (Table 10), which are not very large, allow a statistical analysis of the mean values of blood indices. Small anisocytosis (Fig. 15) authorizes the calculation of the average thickness of erythrocytes.

As the bank voles were investigated in the mountains at the end of September and at the beginning of October, the mean values of their indices were compared with the corresponding data for the Białowieża bank voles (Table 10). It is noteworthy that the mean temperature of these months at Białowieża approximates much to the temperature in the region of Morskie Oko Lake during the catches.

The level of $H b$ of highland specimens is higher than in the Bialowie$\dot{z}$ a bank voles from September, but almost equal to and even somewhat lower than in the lowland specimens in October. The diameter of erythrocytes in the Tatra population is significantly smaller than in the Bia- 
łowieża specimens in September, but larger than in these last specimens from October. The other indices of highland bank voles do not differ from the corresponding values obtained for the Białowieża population in

Table 10.

Comparison of the mean values of blood indices for highland and lowland populations of C. glareolus.

$+=$ statistically significant, $-=$ statistically not significant.

\begin{tabular}{|c|c|c|c|c|c|}
\hline Leoal1t \& Mostb & $=\operatorname{atg}{ }^{1} I X / X$ & $\operatorname{Brazow1}_{I X}^{2}$ & Diff. $I X$ & $B 1 a \geq{ }_{x}^{4}$ & $\underset{1: 2}{5} \times$ \\
\hline Hb. \&" & $18.5 \pm 0.6$ & $17.2 \pm 0.5$ & + & $18.6 \pm 0.7$ & 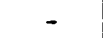 \\
\hline$R B C, m \leq 1: 10 n$ & $12.53 \pm 1.15$ & $12.13 \pm 0.57$ & - & $13.00 \pm 0.65$ & - \\
\hline $\mathrm{MCE}, \quad \gamma \gamma$ & $15.1 \pm 1.1$ & $14.3 \pm 0.8$ & - & $14.4 \pm 0.6$ & - \\
\hline Haonatoor1t s & $30.3 \pm 1.9$ & $48.8 \pm 0.4$ & - & $50.6 \pm 1.7$ & - \\
\hline REC D1aa. $\mu$ & $5.20 \pm 0.17$ & $5.30 \pm 0.09$ & + & $5.09 \neq 0.04$ & + \\
\hline$R B C$ Vol. $\mu^{3}$ & $41.4 \pm 3.7$ & $40.6 \pm 2.0$ & - & $39.3 \pm 1.4$ & - \\
\hline RBC Th1okness $\mu$ & $1.95 \pm 0.15$ & $1.86 \pm 0.13$ & - & $1.93 \pm 0.11$ & - \\
\hline MCEC 6 & $36.5 \pm 1.2$ & \pm 0.8 & - & $36.8 \pm 1.2$ & - \\
\hline
\end{tabular}

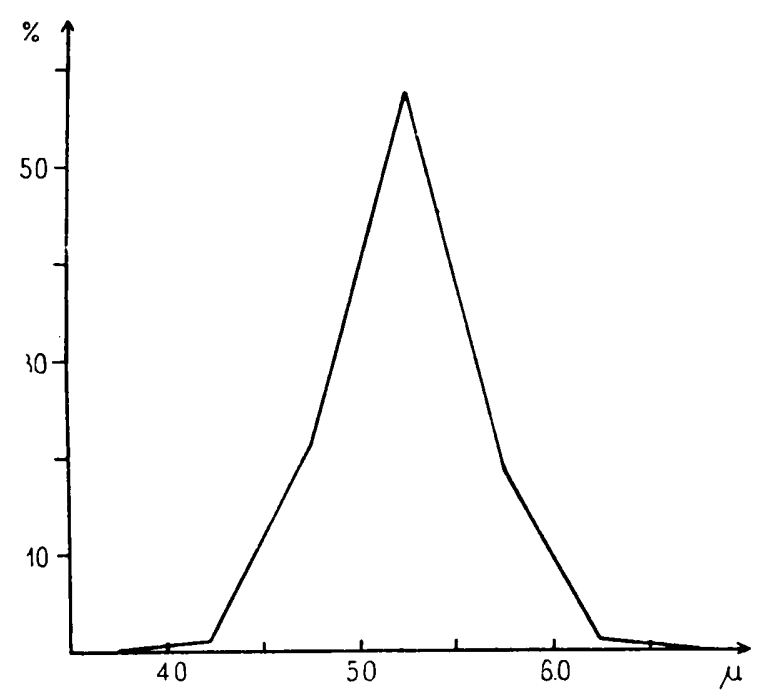

Fig. 15. Anisocytosis curve for highland C. glareolus.

September and October. Therefore, it may be stated that the morphological picture of blcod in C. glareolus living in the mountains at an altitude of $1750 \mathrm{~m}$ does not differ significantly from the blood picture of specimens inhabiting the lowlands (170 $\mathrm{m}$ a.s.l.). 


\section{DISCUSSION}

In view of the rearing prospects of bank voles it would be instructive to compare the blood indices of this species with the data for other laboratory rodents. However, the ununiform conditions of rearing, different methods oi study adopted by different workers and, above all, the lack of full descriptions concerning the morphological blood indices associated with the function of haemoglobin make such comparisons difficult. Nevertheless, it can be established on the basis of the data obtained by different authors for the laboratory mouse that the number of its erythrocytes is about $10.000,000$ and the haemoglobin content does not exceed $16 \mathrm{~g}$. per $100 \mathrm{ml}$. of blcod (B a r ańs ki et al., 1962; H e i$\mathrm{necke}, 1962$ ), The haematocrit of the white mouse, similar to that of laboratory $C$. glareolus, results thus from the larger size of its erythrocytes. This undoubtedly enables the bank vole to maintain the function of haemoglobin at a higher level than in the white mouse. This difference might be explained by the fact that under the conditions of still relatively short laboratory rearing C. glareolus kept a high level of metabolism, characteristic of free-living animals. However, the data for the wild house mouse (L a ng e, 1919), similar to those observed in laboratory white mice, indicate that the differences found are for the most part interspecific ones.

Laboratory rats have still fewer erythrocytes per $1 \mathrm{cu} . \mathrm{mm}$ and less haemoglobin per $100 \mathrm{ml}$. of blood. The $R B C$ diameter is $6.3 \mu(\mathrm{G}$ a r d n e r, $1947 \mathrm{a} ; \mathrm{Pujman}$ et al., 1955) and so it is $1 \mu$ longer than the standard diameter in $C$. glareolus. Nevertheless, the haematocrit of the rat is lower, which emphasizes the physiological significance of the small number of erythrocytes in this species.

The hamster Mesocricetus auratus W a te rhouse, 1839 (S t e w a r t et al., 1944) again has its level of $\mathrm{Hb}$ and haematocrit similar to those in C. glareolus. However, the $R B C$ number, as low as in the rat, with the diameter of erythrocytes longer by about $1.5 \mu$ than in the bank vole, causes that their total surface area in the hamster is much smaller than that in C. glareolus.

The guinea pig has about 5.000 .000 erythrocytes in $1 \mathrm{cu} . \mathrm{mm}$ of blood and its haemoglobin content ranges from about 13 to $14 \mathrm{~g} \%$ (Bilbey $\& \mathrm{Nicol}, 1955$; Gardner, 1947d). These values are therefore lower than those for all the species discussed above.

No doubt, the foregoing divergences must be ascribed to the differences in activity between the members of these species, and so to the varied levels of their metabolism, depending on their body size. It seems natural that the correlations between the morphological indices of blood describing the function of haemoglobin, which is directly involved in 
metabolic processes, are also subordinated to this regularity. An analysis of the normal blood picture of laboratory $C$. glareolus revealed that this species has a higher level of haemoglobin and a larger total surface area of erythrocytes than other Microtidae examined under the same conditions (Kostelecka-Myrcha, 1966a). The species under discussion do not differ in size from the bank vole to the extent that these differences may account for its higher level of $\mathrm{Hb}$ function. For this reason the coincidence of the advantageous conditions of gaseous exchange, characteristic of $C$. glareolus, with the extensive range of this species and its capability of living in very differentiated environments does not seem to be incidental.

The normal range of variation of the blood indices in C. glareolus, derived from laboratory rearing may constitute a fiducial point for ex-perimental studies. The blood picture of these animals cannot however be regarded as a "standard" characteristic of the species. No such formulation is possible until various aspects of variation - not only individual variation - are taken into account ( $\mathrm{G} \mathrm{ębczyński} \mathrm{\&} \mathrm{Ko-}$ stelecka-Myrcha, 1965), although even then there may still be differences between the data obtained from various populations. These differences are probably due to varied developmental phases of these populations and, as has been demonstrated by B e zubik \& Turner (1964), to different degrees of parasitical infestation. Having assumed that there is a normal, not pathological, range of fluctuations of parasitical infestation of populations, which seems right from the physiological and ecological points of view, one should not expect to find these differences great. On the other hand, it must be kept in mind during certain physiological investigations that the standard established concerns animals parasitized to some degree.

The tracing of variation of blood indices in the course of postnatal development made it possible to establish the morphological mechanism ensuring the high level of the function of haemoglobin to adult specimens of this species. The rise in the $H b$ content and in haematocrit, observed from the moment of postnatal anaemia to about the 30th day of life and caused by a rapid increase in the number of erythrocytes accompanied by the simultaneous reduction of their diameter, is the mechanism sought after. Thus, the dependence of the blood picture upon the age of specimens of $C$. glareolus examined resembles the situation in other rodents. M ülle r (1963) investigated this dependence in Lagurus lagurus and found the same regularities in it. The only difference is the lower level of $\mathrm{Hb}$ in newly born specimens of this species than in adult animals, whereas adult bank voles never reach such high values in this index as those found in the young ones immediately after birth. The same 
trend of changes with age as in L. lagurus was observed in the blood picture of the house mouse Mus musculus L in naeus, 1758 (K a labukhov \& Rodionov, 1934). In Citellus pygmaeus (P a llas, 1779), however, these authors found that the level of haemoglobin in adult specimens is lower than in newly-born ones. The general course of variation is, in spite of small differences, the same in all these species. The values of blood indices settle in rodents relatively early, which is also confirmed by the results obtained by $\mathrm{H}$ an kin s (1951), who examined 2-16-month specimens of Sigmodon hispidus S y \& O rd, 1825, and did not find the dependence of these values upon the age of animals. The moment when the values of blood indices settle seems to be connected with the simultaneously terminating development of thermoregulation and the passage to completely independent ways of living. Interesting results have been obtained by examining the variation of blood indices in the postnatal development of $P$. subterraneus (Kosteleck aM y rcha, 1966b). This species is characterized by that it rever has postnatal anaemia and its $\mathrm{Hb}$ level and haematocrit value do not change with age. Functional activity of its haemoglobin is promoted by a mechanism, which therefore consists only in the growth of the number of erythrocytes and the reduction of their diameter, lasting to the 30 th day of life. If postnatal anaemia is treated as a distinct phenomenon, overlapping the age variation in blood indices, it may be assumed that the changes observed in $P$. subterraneus and bringing about an increase in the total surface area of erythrocytes are the basic mechanism that causes the settling of haemoglobin function at the optimal level in adult rodents.

The determination of normal values of any indices in wild-living animals demands the inclusion of their seasonal variation in considerations. It must also be kept in mind that both the age and sex structures of populations change in the annual cycle, which may have a great effect on the results. It was possible to neglect age and sex of animals in studies of seasonal fluctuations of the blood indices of C. glareolus, as has already been explained. It has been found that in the winter and spring the function of haemoglobin reaches its maximum owing to the high level of $\mathrm{Hb}$ and the large total surface area of erythrocytes, whereas in the summer its physiological activity is the smallest. S e a l a n d e r $(1962,1965)$ observed similar tendencies in S. hispidus, Reithrodontomys fulvescens J. A. A $11 \mathrm{e}$, 1894 and 3 species of Peromyscus, $\mathrm{Kalabukhov}$ et al., (1958) in the Gerbillinae and $\mathrm{N}$ ew s o n (1962) in C. glareolus.

Very interesting data concerning the Białowieża population of bank voles were provided by $\mathrm{Kunicki-Goldfinger} \mathrm{\&} \mathrm{Kunicka-}$ 
Goldfinger (1965). They found that the highest level of $H b$ occurs in the spring and early in the autumn, whereas it is low late in the summer and in the winter. Instead, the maximum number of erythrocytes comes round late in the summer and late in the autumn, in the winter it keeps its high value up to the early spring and is the lowest early in the autumn and in the spring. The divergency in the times of the maximum and minimum values of these two indices, which are fairly closely associated with each other by their directly proportional relation, is striking. It is known that the $M C H$, which is a quotient expressed in percentages, $\mathrm{Hb} \mathrm{g} \% /$ haematocrite $\%$, is always constant in the same species, and the changes in the level of haemoglobin and haematocrit ought to be directly proportional. The value of haematocrit is, above all, influenced by the number of erythrocytes, because their diameter in adult animals does not change so much as to have a significant effect on the magnitude of this index. The fluctuations of $R B C$ thickness may be completely left out. Consequently, this divergency must be explained as casual and resulting from the fact that the number of specimens examined during the annual cycle is too small (51 animals).

The data obtained from experiments in which the influence of day length and temperature on the blood indices of $C$. glareolus was studied and the field observations on their seasonal variation made it possible to draw the conclusion that temperature and day length are factors which control the changes in the blood picture in the annual cycle. Temperature seems to exert an influence upon the number of erythrocytes per $1 \mathrm{cu} . \mathrm{mm}$ of blood in this manner that the higher the temperature is, the smaller is the number of erythrocytes. Day length controls the diameter of erythrocytes: the longer the day, the longer the diameter of blood cells.

$\mathrm{K}$ a l a bukhov (1953) ascribes the seasonal fluctuations in the level of $\mathrm{Hb}$ in the yellow-necked field mouse Apodemus flavicollis (M e l$\mathrm{ch}$ i o r, 1834) to the influence of changes in day length. Other authors regard seasonally changing food conditions as a factor regulating the variation of blood indices of large animals in the annual cycle ( $\mathrm{V}$ as e $\mathrm{nko}$ et al., 1953; K o z a k evi č, 1959). The nutritional basis of these animals probably changes much more with seasons than the quality and, above all, the amount of food of small mammals (Górecki \& G ę bc z y n s k a, 1962). Therefore, the influence of temperature on the morphological picture of blood is more frequently observed in rodents ( $\mathrm{S}$ e a l a nde r, 1962, 1965), which seems natural and consistent in view of the connections of this environmental factor with the number of erythrocytes, which is of greatest importance to the seasonal fluctuations of the haemoglobin function. 
The highest level of the $H b$ function, observed in $C$. glareolus in winter and spring, is probably connected with the high oxygen requirements, in the winter on account of its more intense thermoregulation and in the spring because of its increased activity and reproduction. In literature there are many mentions that indicate a direct dependence of the morphological indices of blood upon the seasonally changing general metabolism (S I on im, 1961). Studying. the metabolism of C. glareolus in the annual cycle, Visinescu (1965) obtained its highest value in the spring, the lowest in the summer, and in the autumn she observed a slight increase in the oxygen consumption as compared with the summer values. These data correspond closely to the seasonal fluctuations of the function of haemoglobin described in the present paper.

The correlation between this function and the physiolcgical state of the organism is corroborated by the data obtained for pregnant and lactating females. Pregnancy and lactation exact a vast effort from the mother's organism and cause a significant decrease in the values of morphological indices of blood. The level of haemoglobin drops and the corresponding decrease in the value of haematocrit results from a considerable reduction in the number of erythrocytes, because their diameter increases in length.

Variation with time alone, so far discussed in this paper, does not allow the generalization of the results obtained over the whole species. A comparison of the values of blood indices between the highland and lowland specimens of $C$. glareolus did not show any differences in the blood pictures. It seems that this fact to some extent authorizes us to recognize that all the conclusions obtained for the Białowieża population of bank voles hold good also in the case of the whole species.

$\mathrm{Ka} \mathrm{labukhov}$ (1937) examined the influence of the reduced partial pressure of oxygen on the blood picture in several species of rodents under experimental conditions and found that Apodemus sylvaticus ( $\mathrm{L}$ in na e u s, 1758) and $A$. flavicollis, which inhabit territories up to $2000 \mathrm{~m}$ a.s.l., respond to these conditions by increasing the number of erythrocytes and raising the level of $\mathrm{Hb}$. On the other hand, Apodemus agrarius ( $\mathrm{P}$ all a s, 1771), which lives only in areas below $700 \mathrm{~m}$ a.s.l., shows no faculty for increasing these blood indices. Like $A$. agrarius, C. glareolus also did not respond to the dropped partial pressure of oxygen. Though occurs in the mountains, it has the same blood picture as in lowlands. This should be regarded as a confirmation of its characteristic advantageous conditions of gaseous exchange as compared with many other rodents. It was demontrated by $\mathrm{Kalabukhov} \& \mathrm{Rodionov}$ (1936) that highland populations of some rodents have larger numbers of erythrocytes and higher levels of $\mathrm{Hb}$ than their lowland populations. 
These authors examined A. sylvaticus at an altitude of $1500-1800 \mathrm{~m}$, and so at the altitude at which the blood picture of the highland C. glareolus has been determined. On the other hand, $\mathrm{M}$ or $\mathrm{ris}$ on and his co-workers $(1963,1964)$ found no differences in haemoglobin level and haematocrit value even between varying species of rodents living in the Andes and in lowlands. A comparison of the blood indices of highland Microtus nivalis (M a rtins, 1842) with those of lowland Microtidae (Kostelecka-M yrcha, 1966a) corroborates $\mathrm{M}$ orrison's opinion, but at the same time it also indicates that the value of haematocrite in the lowland and highland species is not the same physiological quality. M. nivalis has fewer erythrocytes than the lowland Microtidae, but their diameter is larger. These facts show that the function of haemoglobin is kept in this species even at a lower degree than in the forms living in lowland areas. It seems therefore that the species which live only in the mountains should be distinguished from those inhabiting both high- and lowlands. In the mountains these last have higher values of morphological indices of blood than their lowland populations and other typical highland species closely related to them systematically. C. glareolus, which shows the same blood picture in both environments, seems really to have better conditions ensuring oxygen to its organism.

The different aspects of variation of the haemoglobin function analysed and expressed by changes in the morphological picture of blood, must be interpreted with caution. To form a full conception of this variation some other indices, especially the total amount of blood, must also be taken into account. If the relative volume of blood decreases, it is difficult to determine whether the changes observed in the morphological picture of blood are only of compensative importance, or whether they actually lead to an increase in the function of haemoglobin. The determination of this index in the postnatal development and in pregnant and lactating females may be of particular importance. It would also be interesting and useful to examine the oxygen content of blood. The frequency of breathing or at least the heart rate should be investigated in the bank voles living in the mountains so as to make it possible to compare the functioning of the circulatory system between the highland and the lowland specimens. However, the objective of the present work has been confined only to the demonstration of morphological mechanisms of blood which have an effect upon the function of haemoglobin in a species having a very wide geographical range.

Acknowledgments: I wish to express my gratitude to Professor Zdzisław $R$ a a b e and Dr. Zdzisław $\mathrm{Puce} k$ for the valuable criticisms and remarks made by them in the course of my work. 


\section{REFERENCES}

1. Alperovich K. B., 1939: Breed, age and sex variations in blood values of rabbits. C. R. Acad. Sci. URSS N. S., 25: 410-413.

2. Akopjan K. A., 1941: Vlijanie faktorov okružajuščej sredy na kartinu krasnoj krovi u krupnogo rogatogo skota. Dokl. Vsesojuzn. Akad. Sel.-hoz. Nauk im. Lenina, 8: 28-31.

3. A rav I. M. \& Mart y n ova V. N., 1952: Kislerodosvjazajušcaja funkcja krovi u karakul'skih ovec na raznyh wysotah. Dokl. A. N. Tadž. SSR., 5: 35-40.

4. Barański S., Czerski P., Krzemińska-Eawkowicz I., Krzymowski T. \& Ławkowicz. W., 1962: Układ krwiotwórczy zwierząt laboratoryjnych. Państw. Wyd. Nauk.: $1-395+49+$ LII. Warszawa.

5. Ba lbierz H., Cogiel F. \& Nikołajczuk M., 1962: Niektóre wskaźniki hematologiczne u nutrii. Zesz. Nauk. WSR Wrocław., Wet., 11, 42: 237-246.

6. Barnecki W., Nikołajczuk M. \& Balbierz H., 1960: Próby ustalenia niektórych norm hematologicznych u lisów srebrzystych. Zesz. Nauk. WSR Wrocław, Wet., 8, 30: 99-108.

7. Bezubik B. \& Turner J. H., 1964: Investigations on the sheep strain of Strongyloides papillosus. IV. The physiological and pathological blood picture of sheep and goats experimentally infected with $S$. papillosus after 5 or 7 serial passages through rabbits. Acta parasitol. polon., 12: 101-116.

8. Bidder H. \& Undritz E., 1948: Der Einfluss von Alter und Geschlecht auf Hämoglobin, Erythrozyten und den Eisengehalt der Leber bei der normal ernährten weissen Laboratoriums Ratte. Helv. Physiol. Pharmacol. Acta, 6, 5: $765-772$.

9. Bilbey D. L. J. \& $\mathrm{Nicol}$ T., 1955: Normal blood picture of the guinea pig. Nature, 176, 4495: 1218.

10. B o e g l e r F., 1963: Die Bedeutung der morphologischen Blutbild Auswertung bei Laboratoriumstiere und das normale Morphohämogramm der Ratte. Z. Versuchstierk., 3, 5: 136-142.

11. B ondarenko G. A., 1952: Izmennenija sostavnyh elementov krovi korov $\mathrm{v}$ tečenije laktacii $\mathrm{v}$ svjazi s različnym urovniem kormlenija. Žurn. obšč. Biol., 13, 6: $464-478$.

12. Bruner H. D., van de Erve J. \& Carls on A. J., 1938: The blood picture of rats from birth to twenty four days of age. J. Physiol., 124: 620-626.

13. Chey mol J. \& Henry R., 1947: La variation des érythrocytes aux cours du dévelopment chez le lapin s'accompagne-t-elle d'une modifikation de la valeur respiratoire du sang. Sang, i8: 299-304.

14. Duvol on S., 1947: Contribution á l'étude hématologique du rat blanc normal. Donneés morphologiques et numeriques (Hemogramme et myelogramme). Sang, 13: 205-234.

15. Ferrar e B., 1951: Hämatologische Studien an der Nutria (Myocastor coypus) in Bezug auf das Geschlecht und an 2 Varietäten. Mitt. I: Das Blut an der Peripherie. Zoot. e. Vet., 6: 157.

16. For eman C., 1956: Notes and blood data on some small mammals of Durham Country, North Carolina. J. Mammal., 37: 427-428.

17. Gardner M. V., 1947a: The blood picture of normal laboratory animals. A reviev of the literature, 1936-1946. The rat. J. Franklin Inst., 243: 77-86. 
18. Gardner M. V., 1947b: The blood picture oi normal laboratory animals. A reviev of the literature, 1936-1946. The mouse. J. Franklin Inst., 243: 172176.

19. Gardner M. V., 1947c: The blood picture of normal laboratory animals. A reviev of the literature, 1936-1946. The hamster. J. Franklin Inst., 243: 434436.

20. Gardner M. V., 1947d: The blood picture of normal laboratory animals. A reviev of the literature, 1936-1946. The guinea pig. J. Franklin Inst., 243: $498-502$.

21. G ębczyński M. \& Kostelecka-Myrcha A., 19665: Zmienność niektórych wskaźników fizjologicznych u ssaków. Kosmos A, 14, 4: 399-404.

22. Gorodeckij V. K., 1962: Ekologo-fizjologičeskie osobennosti krovi severnogo olenija. Tr. In-ta Morf. Život. AN SSSR., 41: 47-57.

23. Górecki A. \& Gębczyńska Z., 1962: Food conditions for small rodents in a deciduous forest. Acta theriol., 6: 275-295.

24. Grüneberg H., 1942: The anaemia of flexed taile mice (Mus musculus L.). J. Genet., 43: 45-68.

25. H ankins R. M., 1951: Values of some constituents of the blood of normal cotton rat, Sigmodon hispidus texianus. J. exper. Zool., 118: 437-442.

26. H e in e cke H., 1962: Das Blutbild der Maus (Eine Übersicht). II. Das normale rote Blutbild. Z. Versuchstierk., 1, 5: 141--159.

27. Holman H. H. \& Dew S. M., 1964: The blood picture of the goat. II. Changes in erythrocytic shape, size and number associated with age. Res. Vet. Sci., 5, 3: $274-285$.

2.4. I r žak L. I., 1964: Dyhatel'naja funkcija krovi $v$ individual'nom razvitii mlekopitajuščih. Izd. Naulsa: 1-183. Moskva.

29. K a la bukhov N. I., 1935: Biologičeskie esobennosti gornyh i ravninnyh podvidov lesnoj myši (Apodemus sylvaticus). Dokl. AN SSSR., 2, 1:

30. Ka labukhov N. I., 1937: Some physiological adaptations of the mountain and plain forms of the wood-mouse (Apodemus sylvaticus) and of other species of mouse-like rodents. J. animal. Ecol., 6: 254-272.

31. K a la bukhov N. I., 1953: Sezonnyje izmenenija reakcji želtogorlyh myšej na vozdejstvije uslovij sredy. Bull. Mosk. Ob-va Ispyt. Prir. Otd. Biol., 58, 3. $25-39$.

32. Kalabukhov N. I., Mokrevi č N. A. \& Petrosjan E. A., 1958: Nekotorye ekologo-fizjologičeskic osobennosti raznych vidov i geografičeskih populacij odnogo vida peščanok (Gerbillinae, Glires, Mammalia). Sov. ekol.-fizj., Tez. dokl. AN SSSR, 1: 20.

33. Kalabukhov N. I. \& Rodionov V. M., 1934: Changes in the blood of animals according to age. I. Changes in the blood of rodents (Mus musculus L. and Citellus pygmaeus $\mathrm{P}$ a l l.) and birds (Passer montanus L. and Larus ridibundus L.) during the period of growth. Fol. haemat., 52: 145-158.

34. K a labukhov N. I. \& R odionov V. M., 1936: Hemoglobin content and number of erythrocytes in the blood of forest mice of the plains and mountains, belonging to the some subspecies (Apodemus sylvaticus ciscaucasicus $\mathrm{Og}$.) and the alternation to these indicators when the habitat changes to a different altitude. Bull. Soc. Nat. Moscou (Biol.), 45: 22-35.

3j. K o r žu ev P. A., 1964: Gemoglobin. Sravnitelnaja fizjologija i biohimija. Izd. Nauka: 1-287. Moskva. 
36. K oržu ev P. A. \& Go l'd far b N. L., 1954: Nekotorye ekologo-fozjologičeskie osobennosti krovi zajcev (beljaka i rusaka) i domašnyh krolikow. Zool. Žurn., $33,6: 1384-1389$.

37. K ostelecka-M y r cha A., 1966a: Hemoglobin, erythrocytes and hematocrit in the blood of some Microtidae under laboratory conditions. Bull. Acad. Pol. Sci. Cl. II, 14, 5: $343-349$.

38. Kostele cka-M y r cha A., 1966b: Erythrocytes, hemoglobin and hematocrit in the postnatal development of Pitymys subterrancus (de Sèlys-Longch a p s, 1835) (Mammalia, Microtidae). Bull. Acad. Pol. Sci. Cl. II, 14, 6: $413-418$.

30. Kostelecka-Myrcha A., 1966c: Morphological indices of the blood of Microtus nivalis (M a rtins, 1842) (Mammalia, Microtidae). Bull. Acad. Pol. Sci. Cl. II, 14, 7: 483-486.

40. K o z a kevi č V. P., 1959: Sezonnye izmennenija soderźanija gemoglobina, čisla leikocitov i sootnošenija ih različnyh form $\mathrm{v}$ krovi želtogo i malogo suslikov Volžsko-uralskih peskov. Gryzuny i borba z nimi, 6: 64-78.

41. Kunicki-Goldfinger W. \& Kunicka-Goldfinger W., 1964: Seasonal variations of some haematological values in small mammals living in natural environment. Acta theriol., 9, 11: 149-163.

42. Kunze H. G., 1954: Die Erythropoese bei einer erblichen Anämie röntgenmutierter Mäuse. Folia haemat., 72: 391-436.

43. L a ng e W., 1919: Untersuchungen über den Hämoglobingehalt, Zahl und Grösse der roten Blutkörperchen, mit besonderer Berücksichtigung der Domestikationseiwirkung. Zool. Jb. (Physiol), 36: 657-698.

44. Li e b J. R. \& W il b e r C. G., 1954: Some hematological studies on the Alaskan ground squirrel. Trans. amer. Micr. Soc., 73: 412-415.

45. M a zurkiewicz M., 1966: Studies on the European hare. XIV. Some physiological characteristics of blood. Acta theriol. 11, 24: 497-503.

46. M or r is o n P. R., 1964: Adaptation and acclimatization of mammals to high altitude. Naval Res., 17, 10: 4-7.

47. Morrison P. R., Kerst K. \& Rosenmann M., 1963: Hematocrit and hemoglobin levels in some Chilean rodents from high and low altitude. Int. J. Biometeor., 7, 1: 45-50.

48. Morris on P. R., Kerst K., R e ynafarie C. \& R a mos J., 1963: Hematocrit and hemoglobin levels in some Peruvian rodents from high and low altitude. Int. J. Biometeor., 7, 1: 51-58.

49. Musacchia X. J., Wilber C. G. \& Gorski T. W., 1955: Hematological studies on mammals from Alaska. J. Mammal., 36: 362-368.

50. M üller G., 1963: Ein Beitrag zur Kenntnis des Blutbildes von Lagurus lagurus Pallas 1773. Z. Versuchstierk., 2: 103-125.

51. N e w s on J., 1962: Seasonal differences in reticulocyte count, hemoglobin level and spleen weight in wild voles. Brit. J. Haemat., 8, 3: 296-302.

52. N ew s on J. \& C hitty D., 1962: Haemoglobin levels, growth and survival in two Microtus populations. Ecology, 43: 733-738.

53. Nikolskaja I. S., 1962: Nekotorye osobennosti krovi i dyhanija karakulskih ovec. Tr. In-ta Morf. Zivot. AN SSSR., 41: 91-103.

54. Pujman V., Prokopova S. \& Reichlova R., 1955 Krevni obraz krysy. Acta Soc. Bohemoslov. Zool., 19, 2: 175-182.

55. R os a de R., 1947: Dati morfologici e biochimici sul sangue del ratto albino. Boll. di Zool., 14, 4/5/6: 53-64. 
56. Rosahn D., Pearce L. \& H u C., 1934: Comparison of the hemocytological constitution of male and female rabbits. J. exper. Med., 60: 686-699.

57. S a l'g a n ska L. O., 1962: Pro morfologiju krovi ondatry. Dokl. AN URSR., 6: s09-811.

58. Schermer S., 1958: Die Blutmorphologie der Laboratoriumstiere. Verl. Barth.: 1-186. Leipzig.

59. Schulz J. \& Muller J., 1962: Haemogram of normal and starved rats. Nature, 196, 4850: 178.

60. S e a lander J. A., 1960: Hematological changes in deer mice acclimated at different ambient temperatures. Amer. J. Physiol., 198: 195-199.

61. S e a lander J. A., 1962: Seasonal changes in blood values of deer mice and other small mammals. Ecology, 43: 107-119.

62. S e a l a n der J. A., 1965: The influence of body size. season, sex age and other factors upon some blood parameters in small mammals. J. Mammal., 45: 598616.

63. Slonim A. D., 1961: Osnovy obščej ekologičeskoj fizjologii mlekopitajuščih. lzd. AN SSSR.: 1-432. Moskva-Leningrad.

64. Smith C., 1932: The post-embryonic development of the erytrocytes of the albino rat. J. Pathol. Bact., 35: 717-726.

65. Stewart M. O., Florio L. \& M ugrage E. R., 1944: Haematological findings in the golden hamster (Cricetus auratus). J. exper. Med., 80, 3: 189196.

66. Stevens L. C. \& M a ckensen J. A., 1958: 'The influence and expresion of a mutation in the mouse. Affecting blood formation the axial skeleton and body size. J. Hered., 49: 153-160.

67. Svihla A. \& Bowman E., 1955: Blood volumes in the golden hamster. J. Mammal., 36: 136-146.

68. S a t a lina A. S., 1949: Izmenenije kartiny krovi karakulskih ovec pod vlijaniem klimata i različnyh uslovij soderžanija. Bull. Sredneazjatsk. gos. In-ta, 28:

69. Vasenko E. P., Borščevskaja E. F. \& Kurenkova V. A., 1953: $\mathrm{K}$ voprosu ob izmenenijah pokazatelej krovi $\mathrm{u}$ ovec $\mathrm{v}$ zavisimosti ot sezona goda $v$ gornyh uslovijah. Tr. In-ta eksp. Biol. AN Kaz. SSR., 1: 147.

70. Visinescu N., 1965: Researches on nicthermal and seasonal variations of energetic metabolism in Clethrionomys glareolus and Apodemus flavicollis. Rev. Roum. Biol., Zool., 10: 183-189.

71. W introbe M. M., 1956: Clinical hematology. Lea \& Fiebiger. Philadelphia.

72. Z a h arjan A. B., 1963: Nekotorye pokazateli periferičeskoj krovi v uslovijah vysokogorija Argaca. Dokl. AN Arm. SSR., 36, 1: 59-64.

Feceived, January 10, 1967.

Polish Academy of Sciences, Mammals Research Institute, Białowieża, woj. Białystok. 


\title{
Alina KOSTELECKA-MYRCHA \\ ZMIENNOSĆ WSKAŻNIKÓW MORFO-FIZJOLOGICZNYCH KRWI \\ CLETHRIONOMYS GLAREOLUS (S C H REER, 1780)
}

\begin{abstract}
Streszczenie
Przeprowadzone badania nad obrazem krwi nornicy rudej pozwalają stwierdzić, że morfologiczny mechanizm adaptacyjny, zapewniający odpowiednio wysoki poziom funkcji hemoglobiny, zależy od środowiskowych i fizjologicznych sytuacji organizmu. Mechanizm ten polega na zmianie zawartości Hb we krwi i podporządkowanej jej, wprost proporcjonalnej zmianie hematokrytu, dzięki czemu wewnętrzkomórkowa koncentracja hemoglobiny jest zawsze prawie jednakowa. Odpowiednia wartość hematokrytu jest rezultatem zmian liczby i rozmiarów erytrocytów. Istotne wydają się tu współzależności między tymi wskaźnikami, kierunek i intensywność tych zmian, określające wielkość sumarycznej powierzchni erytrocytów. Liczba krwinek pozostaje $w$ odwrotnej zależności od temperatury, a ich średnica zmienia się wprost proporcjonalnie do zmian długości dnia. W wyniku tych zależności funkcja hemoglobiny osiąga najwyższy poziom zimą i wiosną a więc w okresach wzmożonego zapotrzebowania na tlen. Liczba i wielkość erytrocytów zależą od wieku badanych zwierząt oraz od takich stanów fizjologicznych jak ciąża i laktacja. Podczas gdy liczba krwinek do trzydziestego dnia rozwoju postnatalnego C. glareolus rośnie, średnica ich maleje, co doprowadza do wydatnego powiększenia sumarycznej powierzchni erytrocytów. Mechanizm ten można uznaí za jeden $\mathrm{z}$ istot.niejszych procesów przygotowujących młodego osobnika do calkowicie samodzielnego trybu życia.

Porównanie obrazu krwi C. glareolus z obrazem krwi innych Microtidac trzymanych $w$ hodowli oraz brak różnic między morfologicznymi wskaźnikami krwi górskich i nizinnych populacji nornic pozwala przypuszczać, że gatunek ten dysponuje lepszymi niż wiele innych gryzoni, warunkami wymiany gazowej. Fakt ten wydaje się w poważnym stopniu uzasadniać możliwość zasiedlania różnorodnych środowisk i szeroki zasiçg występowania nornicy rudej.
\end{abstract}

